Pacific Northwest

National Laboratory

Operated by Battelle for the

U.S. Department of Energy

\section{0-Area VOC Program Slug Test Characterization Results for Selected Test/Depth Intervals Conducted During the Drilling of Well 399-3-21}

F. A. Spane

July 2007

Prepared for the U.S. Department of Energy under Contract DE-AC05-76RL01830 


\title{
DISCLAIMER
}

This report was prepared as an account of work sponsored by an agency of the United States Government. Neither the United States Government nor any agency thereof, nor Battelle Memorial Institute, nor any of their employees, makes any warranty, express or implied, or assumes any legal liability or responsibility for the accuracy, completeness, or usefulness of any information, apparatus, product, or process disclosed, or represents that its use would not infringe privately owned rights. Reference herein to any specific commercial product, process, or service by trade name, trademark, manufacturer, or otherwise does not necessarily constitute or imply its endorsement, recommendation, or favoring by the United States Government or any agency thereof, or Battelle Memorial Institute. The views and opinions of authors expressed herein do not necessarily state or reflect those of the United States Government or any agency thereof.

\author{
PACIFIC NORTHWEST NATIONAL LABORATORY \\ operated by \\ BATTELLE \\ for the
UNITED STATES DEPARTMENT OF ENERGY
under Contract DE-ACO5-76RL01830

Printed in the United States of America
Available to DOE and DOE contractors from the Office of Scientific and Technical Information,
P.O. Box 62, Oak Ridge, TN 37831-0062;
ph: (865) 576-8401
fax: (865) 5765728
email: reports@adonis.osti.gov

\author{
Available to the public from the National Technical Information Service, \\ U.S. Department of Commerce, 5285 Port Royal Rd., Springfield, VA 22161 \\ ph: (800) 553-6847 \\ fax: (703) 605-6900 \\ email: orders@nits.fedworld.gov \\ online ordering: http://www.ntis.gov/ordering.htm
}




\title{
300-Area VOC Program Slug Test Characterization Results for Selected Test/Depth Intervals Conducted During the Drilling of Well 399-3-21
}

\author{
F. A. Spane
}

July 2007

Prepared for the U.S. Department of Energy

under Contract DE-AC05-76RL01830

Pacific Northwest National Laboratory

Richland, Washington 99352 


\section{Executive Summary}

This report presents brief test descriptions and analysis results for multiple, stress-level slug tests that were performed at selected test/depth intervals within well 399-3-21 as part of the 300-Area volatile organic compound characterization program. The test intervals were characterized as the borehole was advanced to its final drill depth $(45.7 \mathrm{~m})$ and before its completion as a monitor-well facility. The primary objective of the slug tests was to provide information pertaining to the vertical distribution of hydraulic conductivity with depth at this location and to select the final screen-depth interval for the monitor well. This type of characterization information is important for predicting/simulating contaminant migration (i.e., numerical flow/transport modeling) and designing proper monitor-well strategies within this area. Similar selected test/depth intervals were characterized previously at four surrounding 300-Area wells: 399-1-23, 399-3-18, 399-3-19, and 399-3-20. Results for the previous well characterizations are presented in Williams et al. (2007). Figure S.1 shows the location of these previously characterized wells and their distance relationships to well 399-3-21 (Figure S.1). The closest previously characterized well is well 399-3-20, which is located at a distance of $6.30 \mathrm{~m}$ from well 399-3-21.

Overall, the test results obtained from multiple, stress-level slug tests conducted during drilling and borehole advancement provide detailed information concerning the vertical distribution of hydraulic conductivity for hydrogeologic units comprising the unconfined aquifer at this test-well location. The individual test/depth intervals were sited to provide hydraulic-property information for the highly permeable Hanford formation (Unit 1) and within the upper, middle, and lower sections of the underlying, less permeable Ringold Formation (Unit 5). A total of eight discrete depth intervals were tested (Table S.1) during the course of borehole advancement. Complications were experienced during the testing of two of the depth intervals (Tables S.1 and S.2; Zones 1B and 2B), which eliminated the possibility of characterizing these test intervals. Analysis of the slug test results for the six successfully tested depth intervals indicates a relatively narrow-range for test zones within the Ringold Formation, ranging between 0.27 to $2.03 \mathrm{~m} /$ day. The well 399-3-21 values fall within the lower range (0.04 to $41.2 \mathrm{~m} /$ day; geometric mean $=2.38 \mathrm{~m} /$ day) for 10 other Ringold Formation test/depth intervals recently obtained for test characterization boreholes in the 300-Area, as reported in Williams et al. (2007).

One high-permeability Hanford formation test/depth interval characterized at well 399-3-21 (Zone 1A) provided a permeability estimate of $568 \mathrm{~m} /$ day. This estimated value falls within the general range of $>100 \mathrm{~m} /$ day to $>2,000 \mathrm{~m} /$ day previously reported by Williams et al. (2007) for this hydrogeologic unit, which is based on recent 300-Area slug test characterizations.

The hydraulic-conductivity vertical depth profile for well 399-3-21, which is based on the test/depth interval test characterizations, is shown in Figure S.2(a). For comparison purposes, the hydraulic conductivity depth profile for adjacent well 399-3-20 is also presented in Figure S.2(b). In comparing the two depth profiles, it is interesting to note that a significant difference in hydraulic-conductivity estimates (i.e., 1.04 versus $33.4 \mathrm{~m} /$ day) is exhibited for an over-lapping Ringold Formation test/depth interval at well 399-3-21 (Zone 2A; 25.88 to 27.28 m) and adjacent well 399-3-20 (Zone D; 25.30 to $27.58 \mathrm{~m}$ ), respectively; note: the lateral well distance separation $=6.30 \mathrm{~m}$. Currently, it is not known whether the exhibited difference in hydraulic conductivity values is real (i.e., reflective of lateral heterogeneity within the Ringold Formation) or whether the test results for this depth zone at well 399-3-20 are biased by possible hydraulic communication with the overlying Hanford formation unit (i.e., due to unrecognized 
drill casing by-pass during testing). It is interesting to note, however, that hydraulic communication with the overlying Hanford formation unit was detected during testing of Zone 2B at well 399-3-21, which also encompasses this test/depth interval.

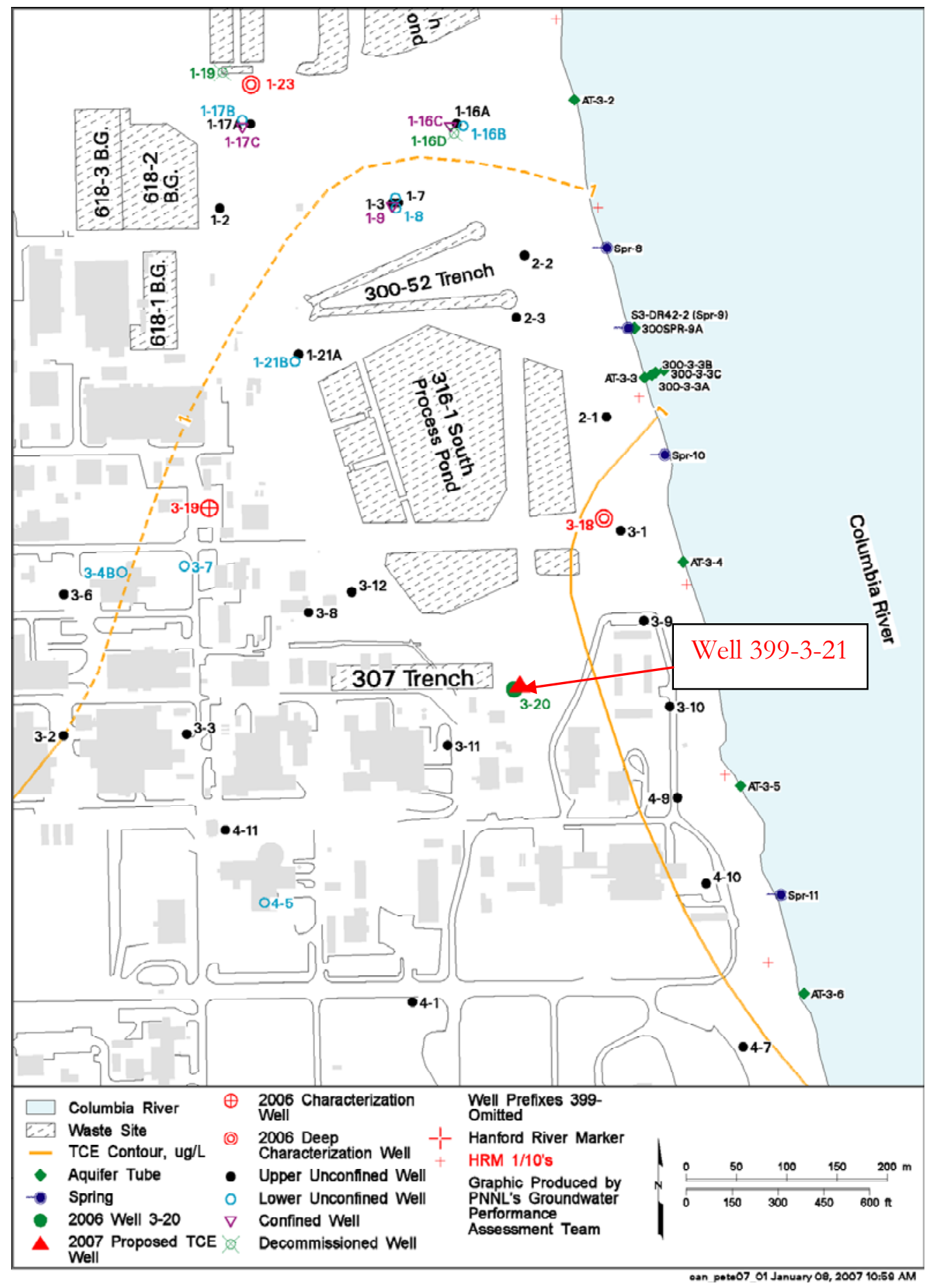

Figure S.1. Location Map Showing 300-Area Test Characterization Well Sites 
(a)

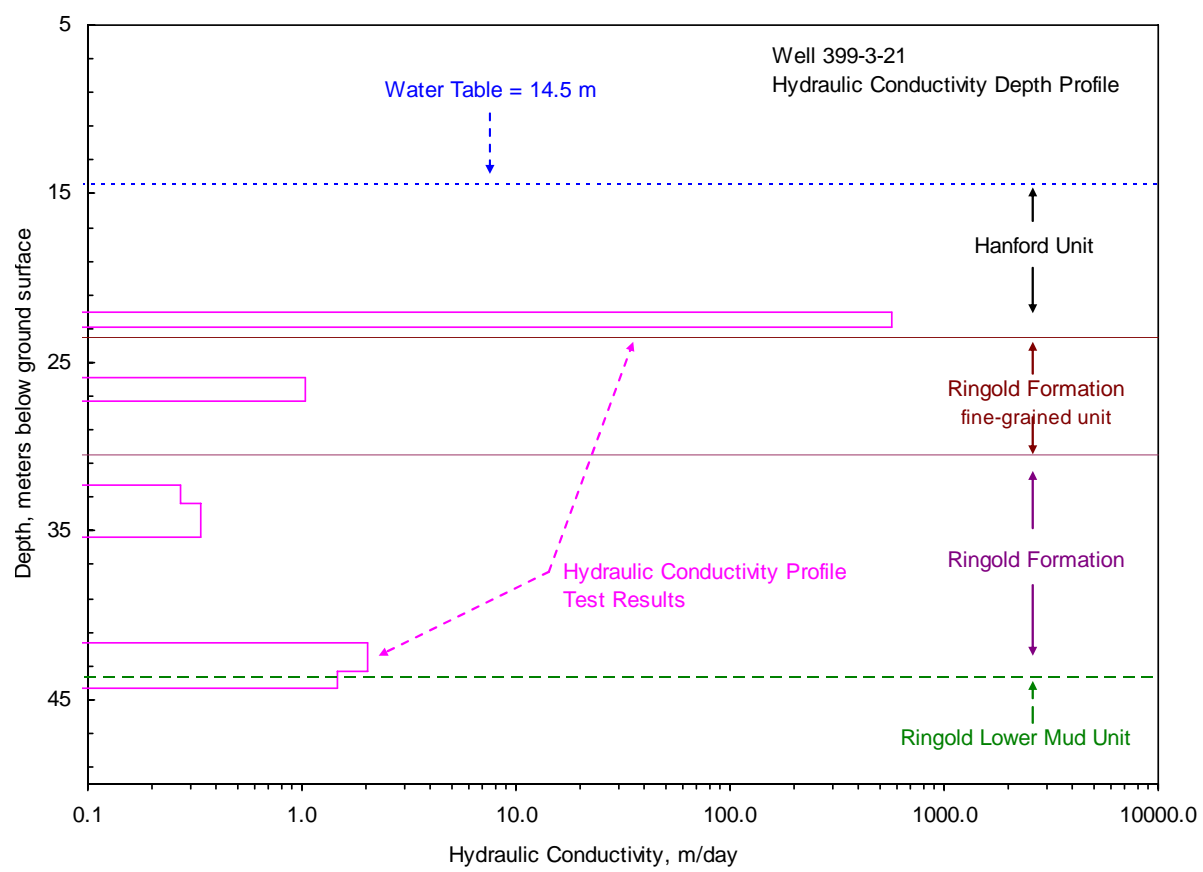

(b)

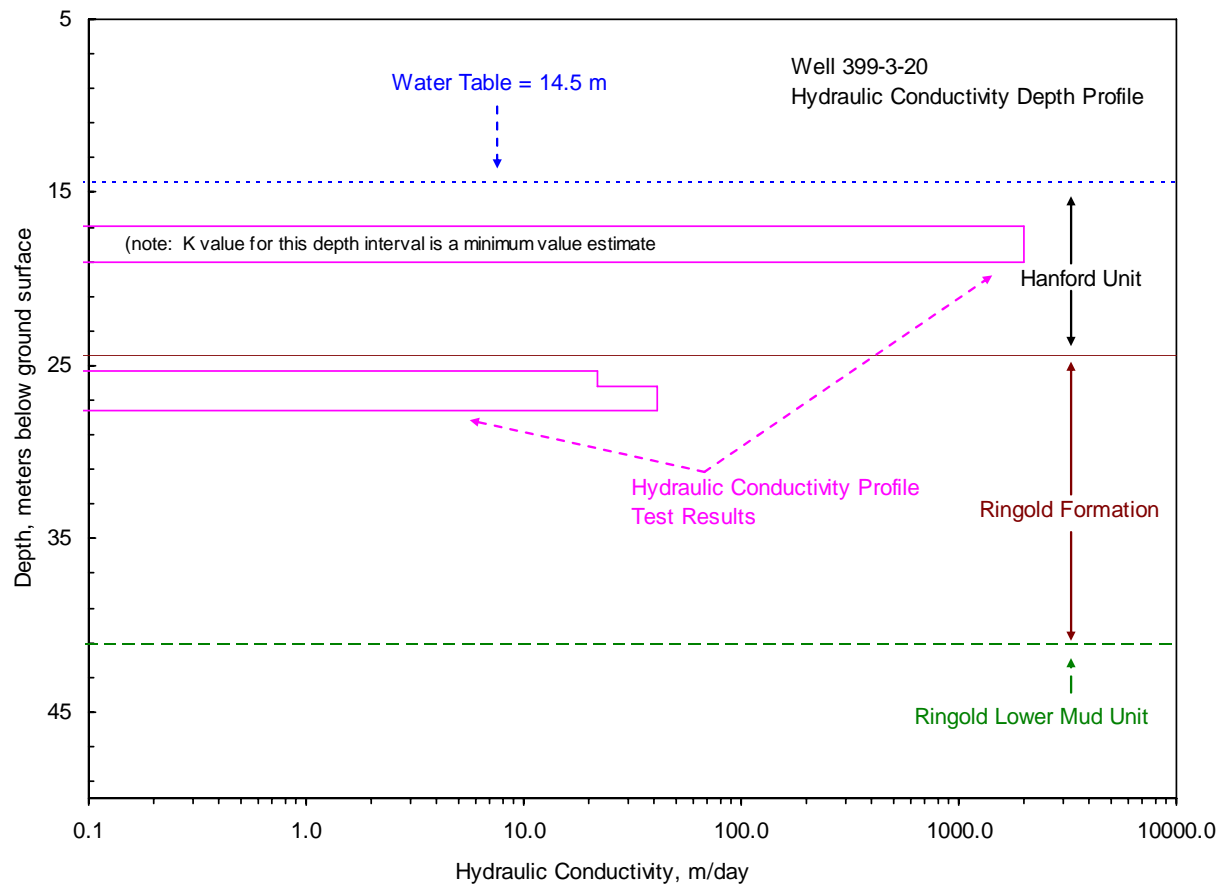

Figure S.2. Vertical Distribution of Hydraulic Conductivity for Selected Test/Depth Intervals Based on Field Slug Test Characterization at: a) Well 399-3-21 and b) Adjacent Well 399-3-20 
Table S.1. Slug Test Characteristics for Discrete Test/Depth Intervals at Well 399-3-21

\begin{tabular}{|c|c|c|c|c|c|c|}
\hline \multirow[b]{2}{*}{$\begin{array}{l}\text { Test } \\
\text { Zone }\end{array}$} & \multicolumn{4}{|c|}{ Test Parameters } & \multirow{2}{*}{$\begin{array}{c}\text { Diagnostic Slug } \\
\text { Test Response } \\
\text { Model }\end{array}$} & \multirow[b]{2}{*}{ Hydrogeologic Unit Tested $^{(a)}$} \\
\hline & $\begin{array}{l}\text { Test } \\
\text { Date }\end{array}$ & $\begin{array}{l}\text { \# Slug } \\
\text { Tests }\end{array}$ & $\begin{array}{c}\text { Depth to } \\
\text { Water, } \\
\text { m bgs }\end{array}$ & $\begin{array}{c}\text { Test/Depth } \\
\text { Interval, } \\
\text { m bgs }\end{array}$ & & \\
\hline Zone 1A & 4/18/07 & 8 & 14.48 & $\begin{array}{c}22.04-22.92 \\
(0.88)\end{array}$ & $\begin{array}{l}\text { Under-Damped } \\
\text { (oscillatory) }\end{array}$ & $\begin{array}{l}\text { Hanford formation } \\
\text { (Unit } 1 \text { ) }\end{array}$ \\
\hline Zone 1B* & 4/18/07 & 3 & 14.48 & $\begin{array}{c}21.09-22.92 \\
(1.83)\end{array}$ & $\begin{array}{c}\text { Over-Damped* } \\
\text { (exponential-decay) }\end{array}$ & $\begin{array}{l}\text { Hanford formation } \\
\text { (Unit 1) }\end{array}$ \\
\hline Zone 2A & 4/23/07 & 4 & 14.39 & $\begin{array}{c}25.88-27.28 \\
(1.40)\end{array}$ & $\begin{array}{c}\text { Elastic/Over-Damped } \\
\text { (exponential-decay) }\end{array}$ & $\begin{array}{l}\text { Ringold Formation - } \\
\text { fine-grained unit } \\
\text { (Unit 5) }\end{array}$ \\
\hline Zone $2 \mathrm{~B}^{* *}$ & 4/23/07 & 8 & 14.39 & $\begin{array}{c}24.96-27.28 \\
(2.32)\end{array}$ & $\begin{array}{c}\text { Over-Damped** } \\
\text { (exponential-decay) }\end{array}$ & $\begin{array}{l}\text { Ringold Formation } \\
\text { (Unit 5) }\end{array}$ \\
\hline Zone 3A & $\begin{array}{l}4 / 30- \\
5 / 1 / 07\end{array}$ & 4 & 14.39 & $\begin{array}{c}\text { 33.38-35.36 } \\
(1.98)\end{array}$ & $\begin{array}{c}\text { Over-Damped } \\
\text { (exponential-decay) }\end{array}$ & $\begin{array}{l}\text { Ringold Formation } \\
\text { (Unit 5) }\end{array}$ \\
\hline Zone 3B & $5 / 1 / 07$ & 4 & 14.40 & $\begin{array}{c}32.28-34.78 \\
(2.50)\end{array}$ & $\begin{array}{c}\text { Over-Damped } \\
\text { (exponential-decay) }\end{array}$ & $\begin{array}{l}\text { Ringold Formation } \\
\text { (Unit 5) }\end{array}$ \\
\hline Zone 4A & $5 / 4 / 07$ & 8 & 14.23 & $\begin{array}{c}43.28-44.32 \\
(1.04)\end{array}$ & $\begin{array}{c}\text { Over-Damped } \\
\text { (exponential-decay) }\end{array}$ & $\begin{array}{l}\text { Ringold Formation } \\
\text { (Unit 5) }\end{array}$ \\
\hline Zone 4B & $5 / 7 / 07$ & 6 & 14.16 & $\begin{array}{c}41.61-44.26 \\
(2.65) \\
\end{array}$ & $\begin{array}{c}\text { Over-Damped } \\
\text { (exponential-decay) }\end{array}$ & $\begin{array}{l}\text { Ringold Formation } \\
\text { (Unit 5) }\end{array}$ \\
\hline \multirow{2}{*}{\multicolumn{7}{|c|}{$\begin{array}{l}\text { Note: For all test/depth zones, } \mathrm{r}_{\mathrm{c}}=0.051 \text { meters; } \mathrm{r}_{\mathrm{w}}=0.1492 \text { meters. } \\
\text { (a) Hydrogeologic unit number in parentheses indicates the relevant groundwater-flow model layer, as described in Thorne } \\
\text { et al. (1993). } \\
\text { * Slug test characterization adversely affected by silt incursion and plugging of the well screen; test responses are considered } \\
\text { to be non-representative, and no test analysis results are reported. }\end{array}$}} \\
\hline & & & & & & \\
\hline \multicolumn{7}{|c|}{$\begin{array}{l}\text { ** Slug test characterization adversely affected by casing by-pass (leakage); test responses are considered to be non- } \\
\text { representative, and no test analysis results are reported }\end{array}$} \\
\hline
\end{tabular}





\section{Contents}

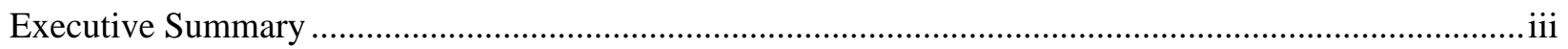

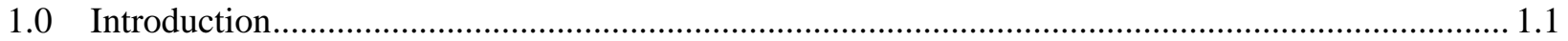

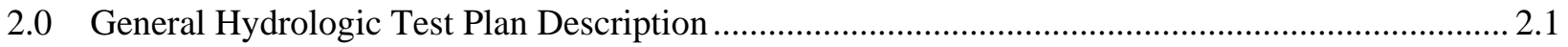

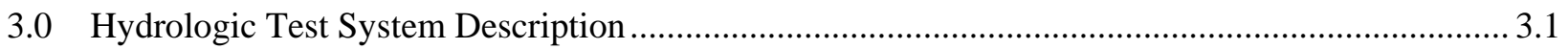

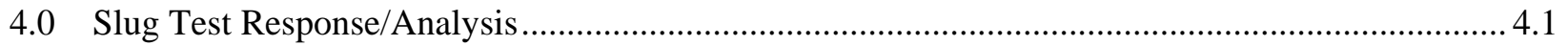

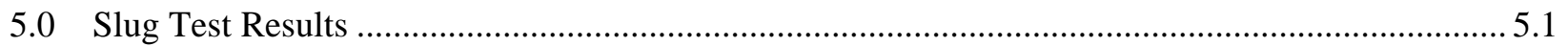

5.1 Zone 1A (Depth: 22.04 to $22.92 \mathrm{~m}$ ) ......................................................................................... 5.5

5.2 Zone 1B (Depth: 21.09 to $22.92 \mathrm{~m})$........................................................................................... 5.5

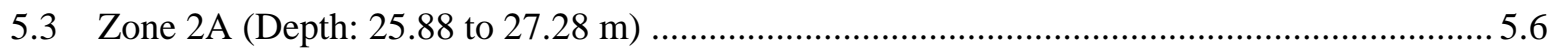

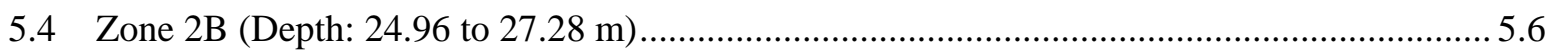

5.5 Zone 3A (Depth: 33.38 to $35.36 \mathrm{~m})$.................................................................................... 5.7

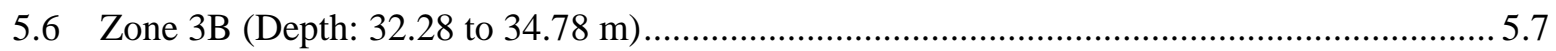

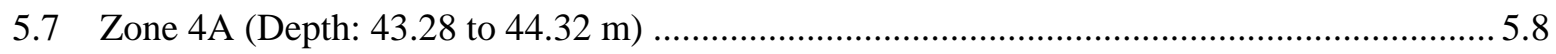

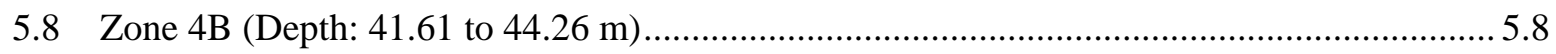

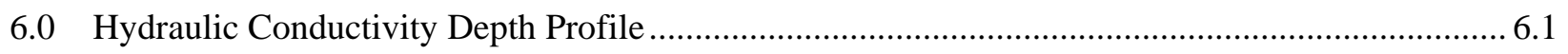

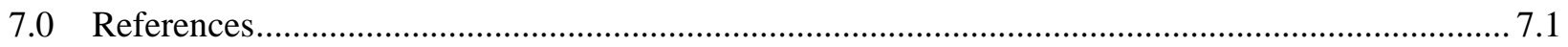

Appendix A. Well 399-3-21 Borehole Log ........................................................................................ A.1

Appendix B. Miscellaneous Test Equipment Pictures ............................................................................... 


\section{Figures}

S.1. Location Map Showing 300-Area Test Characterization Well Sites ................................................ iv

S.2. Vertical Distribution of Hydraulic Conductivity for Selected Test/Depth Intervals Based on Field Slug Test Characterization at: a) Well 399-3-21 and b) Adjacent Well 399-3-20 ................ v

3.1. General Slug Test Configuration Within Well 399-3-21............................................................ 3.2

3.2. Packer/Well-Screen Assembly Dimensions (modified drawing provided by Jake Horner).............. 3.3

4.1. Diagnostic Slug Test Response (for Well 399-3-21 test conditions).......................................... 4.2

5.1. Selected High-K Type-Curve Analysis Plot: Well 399-3-21; Test Zone 1A, Test SI \#2 ................. 5.2

5.2. Selected Type-Curve Analysis Plot: Well 399-3-21; Test Zone 2A, Test SW \#2 _........................ 5.2

5.3. Selected Type-Curve Analysis Plot: Well 399-3-21; Test Zone 3A, Test SW \#2 .......................... 5.3

5.4. Selected Type-Curve Analysis Plot: Well 399-3-21; Depth Zone 3B, Test SW \#1 ….................... 5.3

5.5. Selected Type-Curve Analysis Plot: Well 399-3-21; Depth Zone 4A, Test SW \#3 ........................ 5.4

5.6. Selected Type-Curve Analysis Plot: Well 399-3-21; Depth Zone 4B, Test SW \#2 ........................ 5.4

\section{Tables}

S.1. Slug Test Characteristics for Discrete Test/Depth Intervals at Well 399-3-21_...............................vi

S.2. Slug Test Analysis Results for Discrete Test/Depth Intervals at Well 399-3-21............................vii

5.1. Vertical Hydraulic Conductivity Distribution at Well 399-3-21, Based on Discrete Depth Interval Slug Test Results 


\subsection{Introduction}

Pacific Northwest National Laboratory conducted multiple, stress-level slug tests at selected test/depth intervals within well 399-3-21 as part of the 300-Area volatile organic compound (VOC) characterization program at the Hanford Site in Washington State for the U.S. Department of Energy. The test intervals were characterized as the borehole was advanced to its final drill depth $(45.7 \mathrm{~m})$ and before its completion as a monitor-well facility. The primary objective of the slug tests was to provide information pertaining to the vertical distribution of hydraulic conductivity with depth at this location and to select the final screen-depth interval for the monitor well. This type of characterization information is important for predicting/simulating contaminant migration (i.e., numerical flow/transport modeling) and designing proper monitor-well strategies within this area.

Section 2 describes the general hydrologic test plan used to perform the series of multiple, stress-level slug tests for each isolated test-interval section. Section 3 describes the hydrologic test system employed during the test characterization. Section 4 discusses slug test response and analysis. Section 5 presents pertinent information describing slug testing activities and analysis results for the test/depth zones that were hydrologically characterized at the 300-Area/VOC well 399-3-21 as it was advanced to its final completion depth. Results are described for Zone 1A, 1B, 2A, 2B, 3A, 3B, 4A, and 4B. Section 6 describes depth profiles for hydraulic conductivity at well 399-3-21 and adjacent well 399-3-20. 


\subsection{General Hydrologic Test Plan Description}

The following general hydrologic test plan discussion is taken primarily from similar slug test characterization-program descriptions presented previously in Spane. ${ }^{(a, b)}$ Hydrologic testing was implemented when the approximate targeted depth interval within the upper, middle, and lower sections of the unconfined aquifer were reached during drilling. To prepare the test zone for slug test characterization, a packer/well-screen test assembly was lowered to the bottom of the borehole, and the drill casing was retracted, exposing open borehole test-sections varying in length from 0.9 to $2.7 \mathrm{~m}$. The packer was then inflated to isolate the well-screened/test interval and testing string from the inside of the drill casing.

A series of multiple, stress-level slug tests were performed for each isolated test-interval section. The reason for using a multi-stress level approach was to determine whether the associated slug test responses exhibited either a variable or stress-level dependence. As noted in Butler (1997) and Spane et al. (2003), tests exhibiting either variable or stress-level dependence can provide valuable information pertaining to the presence of dynamic well skin or non-linear (i.e., turbulence) test-response conditions occurring within the test section. General slug test stress levels applied during testing were designed to be within the range of $\sim 0.6$ to $0.9 \mathrm{~m}$ for lower stress tests and $\sim 1.4 \mathrm{~m}$ for higher stress tests. The slug tests were initiated with several slugging rods of different, known displacement volumes. For most test zones, three or more multi-stress slug tests were conducted. Efforts were made to allow individual slug tests to approach full recovery before starting the next slug test within the characterization sequence. A widerange in recovery times was expected based on the anticipated range in permeability conditions. For example, Spane et al. (2001a, 2001b, 2002, 2003) and Spane and Newcomer (2004) report recovery times as rapid as $<15 \mathrm{sec}$ for high-permeability test intervals (e.g. Hanford formation) to $>10 \mathrm{~min}$ for lower permeability Ringold Formation test zones. A description of the hydrologic test system used during slug test characterization is provided in the following report section.

(a) FA Spane. 2003. Slug Test Characterization Results for Multi- Test/Depth Intervals Conducted During the Drilling of WMA-C Well 299-E27-22 (C4124). Letter report to Jane Borghese (Fluor Hanford, Inc.), October 8, 2003, 28p.

(b) FA Spane. 2005. Slug Test Characterization Results for Multi-Test/Depth Intervals Conducted During the Drilling of WMA-BX-BY Well 299-E33-49. Letter report to Jane Borghese (Fluor-Hanford, ORP) January 10, 2005, 31p. 


\subsection{Hydrologic Test System Description}

Figures 3.1 and 3.2 show the general test-system configuration used for slug tests conducted during the drilling and testing of 300-Area well 399-3-21. Slug tests used during the depth-interval characterizations were conducted using only slugging rods for all test zones (i.e., no pneumatic slug tests were performed). Salient features of the test system used at well 399-3-21 include the downhole packer/well-screen test assembly, a downhole pressure transducer, and a surface datalogger system. The drill-casing string used for borehole advancement during the drilling of well 399-3-21 had I.D./O.D. dimensions of 0.273 $\mathrm{m} / 0.298 \mathrm{~m}$, respectively. As shown in Figures 3.1 and 3.2, an inflatable packer was used to seal and isolate the test interval and testing string from the encompassing drill-casing area. Test-interval isolation was verified by adding $20 \mathrm{~L}$ of water above the packer (i.e., in the annular area between the testing string and drill casing), both at the beginning and end of the testing sequence. Two different well-screen configurations were used during testing. A 1.44-m length of 0.102-m I.D., 10-slot, well-screen section was attached below the packer to maintain an open section for testing after retracting the drill casing for the initial test-depth intervals (Zones $1 \mathrm{~A}$ and $1 \mathrm{~B}$ ), while a combined 2.97-m length of 0.102-m I.D. wellscreen (1.53 $\mathrm{m}$ of 20 slot and $1.44 \mathrm{~m}$ of 10 -slot) were used during the testing of all subsequent test/depth intervals. Selected pictures of the packer/well-screen test assembly are shown in Appendix B. A Druck, Inc., pressure transducer strain-gauge, 0 to $34.5 \mathrm{kPa}$ (0 to $5 \mathrm{psig}$ ) pressure transducer was installed below the fluid-column surface within the test-casing string to monitor downhole test interval response before and during slug testing (see Figure 3.1). Pressure-transducer measurements were recorded using a Campbell Scientific, Inc. model CR-10X ${ }^{\mathrm{TM}}$ data logger. 


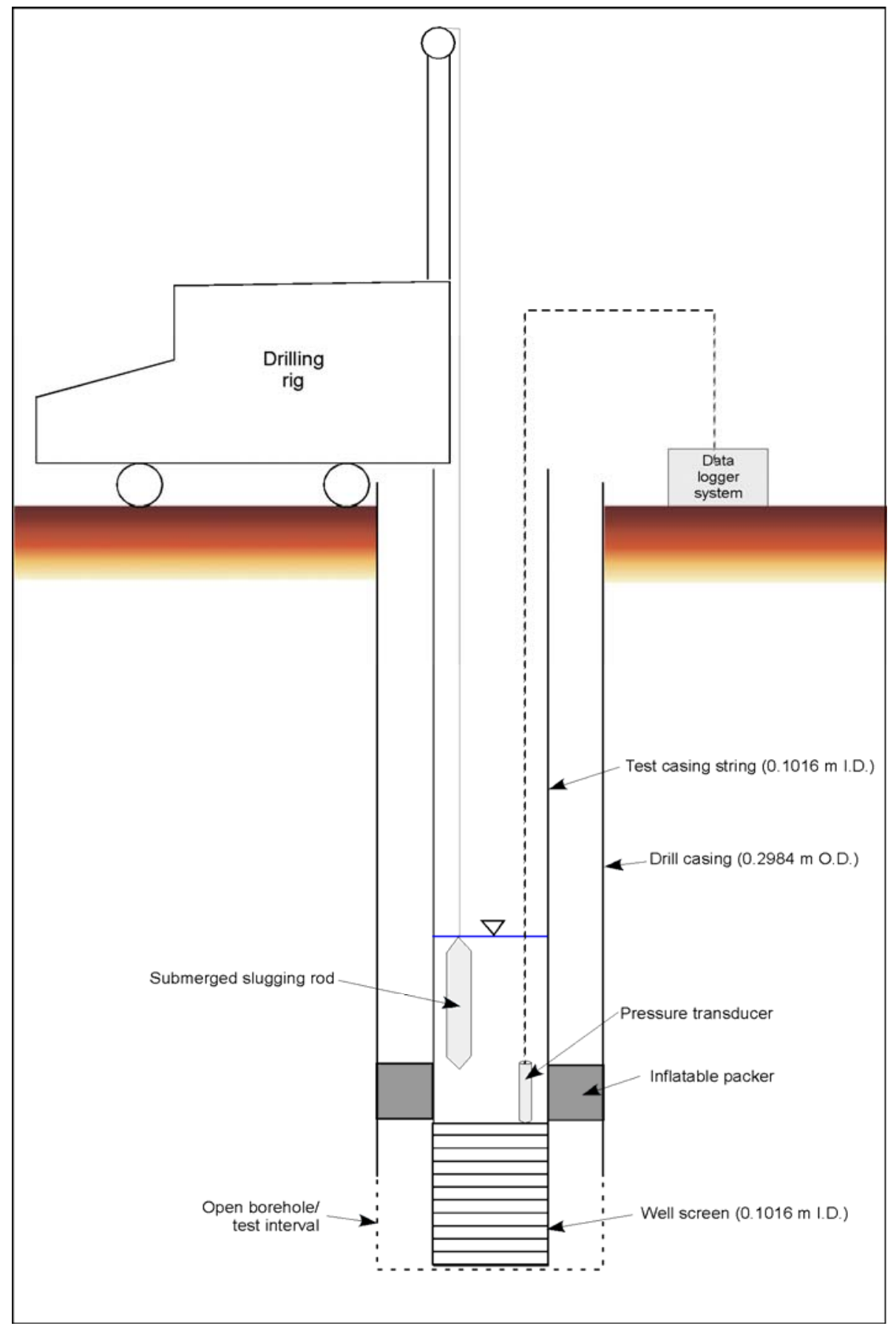

Figure 3.1. General Slug Test Configuration Within Well 399-3-21 

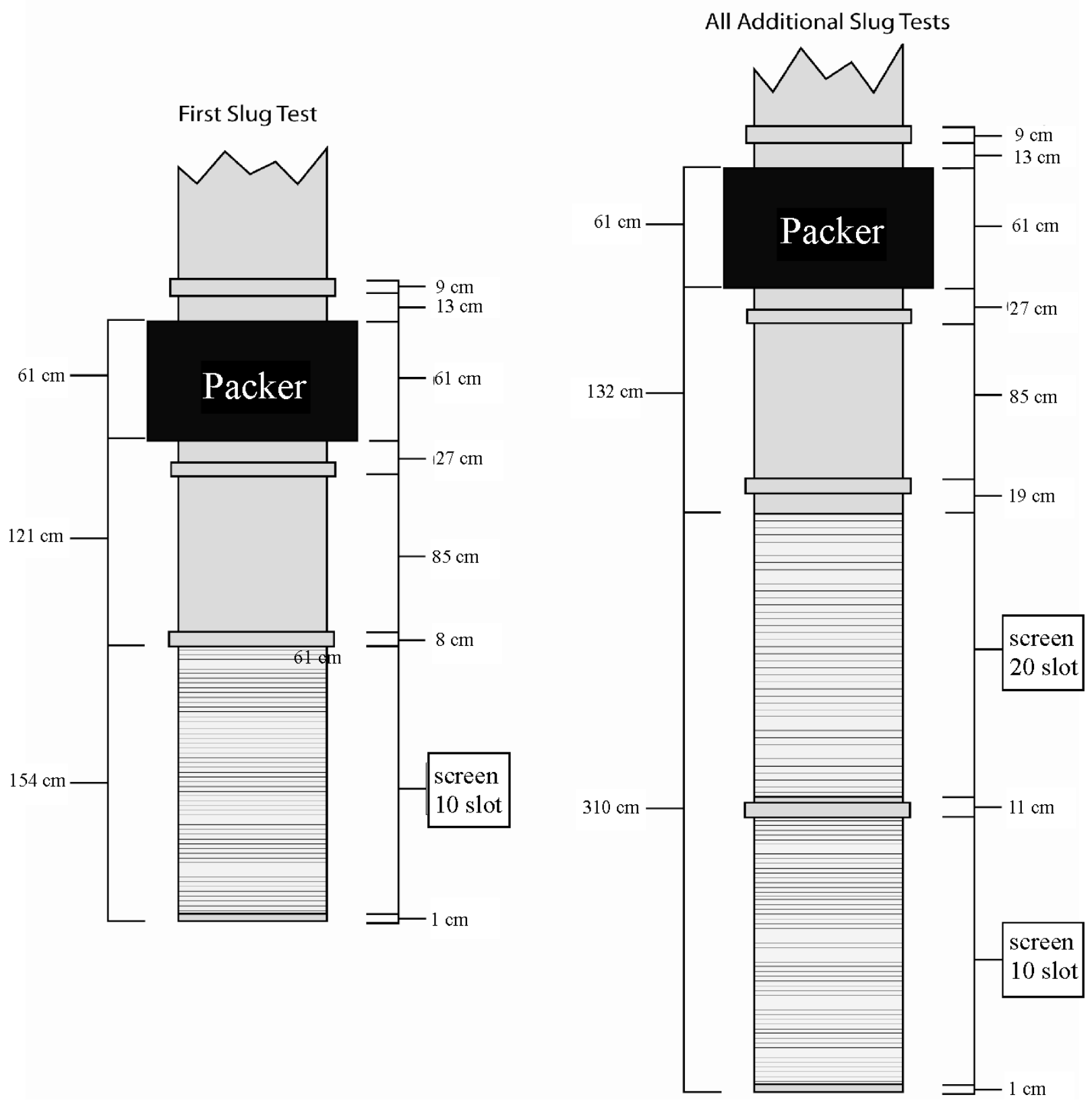

Figure 3.2. Packer/Well-Screen Assembly Dimensions (modified drawing provided by Jake Horner) 


\subsection{Slug Test ResponselAnalysis}

The following discussion pertaining to slug test response and analysis is taken primarily from Spane. ${ }^{(a, b)}$ As shown in Figure 4.1 and discussed in Butler (1997) and Spane et al. (2003b), water levels within a test well can respond in one of three ways to the instantaneously applied stress of a slug test. These response model patterns are 1) an over-damped response, where the water levels recover in an exponentially decreasing recovery pattern, 2) an underdamped response, where the slug test response oscillates above and below the initial static, with decreasing peak amplitudes with time, and 3) critically damped, where the slug test behavior exhibits characteristics that are transitional to the over- and under-damped response patterns. Factors that control the type of slug test response model that will be exhibited within a well include a number of aquifer properties (hydraulic conductivity) and well-dimension characteristics (wellscreen length, well-casing radius, well-radius, aquifer thickness, fluid-column length) and can be expressed by the response damping parameter, $C_{D}$, which Butler (1997) reports for unconfined aquifer tests as:

$$
\mathrm{C}_{\mathrm{D}}=\left(\mathrm{g} / \mathrm{L}_{\mathrm{e}}\right)^{1 / 2} \mathrm{r}_{\mathrm{c}}^{2} \ln \left(\mathrm{R}_{\mathrm{e}} / \mathrm{r}_{\mathrm{w}}\right) /(2 \mathrm{~K} \mathrm{~L})
$$

where $\quad \mathrm{g}=$ acceleration due to gravity

$\mathrm{L}_{\mathrm{e}}=$ effective well water-column length

$\mathrm{r}_{\mathrm{c}}=$ well casing radius; i.e., radius of well water-column that is active during testing

$\mathrm{R}_{\mathrm{e}}=$ effective test radius parameter; as defined by Bouwer and Rice (1976)

$\mathrm{r}_{\mathrm{w}}=$ well radius

$\mathrm{K}=$ hydraulic conductivity of test interval

$\mathrm{L}=$ well-screen length.

Given the multitude of possible combinations of aquifer properties, well-casing dimensions, and test interval lengths, no universal $C_{D}$ value ranges can be provided that describe slug test response conditions. However, for various combinations anticipated for testing at well 399-3-21 during drilling, the following general guidelines on slug test response prediction are provided:

- $\mathrm{C}_{\mathrm{D}}>3=$ over-damped response

- $\mathrm{C}_{\mathrm{D}} 1-3=$ critically-damped response

- $\mathrm{C}_{\mathrm{D}}<1=$ under-damped response.

The slug test response patterns shown in Figure 4.1 are based on Equation 1, and general test conditions encountered at well 399-3-21 are given.

Over-damped test response generally occurs within stress wells monitoring test formations of low to moderately high hydraulic conductivity (e.g., Ringold Formation) and are indicative of test conditions

(a) FA Spane. 2003. Slug Test Characterization Results for Multi- Test/Depth Intervals Conducted During the Drilling of WMA-C Well 299-E27-22 (C4124). Letter report to Jane Borghese (Fluor Hanford, Inc.), October 8, 2003, 28p.

(b) FA Spane. 2005. Slug Test Characterization Results for Multi-Test/Depth Intervals Conducted During the Drilling of WMA-BX-BY Well 299-E33-49. Letter report to Jane Borghese (Fluor-Hanford, ORP) January 10, 2005, 31p. 
where frictional forces (i.e., resistance of groundwater flow from the test interval to the well) are predominant over test-system inertial forces. Most of the well 399-3-21 test intervals exhibited overdamped response characteristics. For slug tests exhibiting over-damped behavior, two different methods can be used for the slug test analysis: the semiempirical, straight-line analysis method described in Bouwer and Rice (1976) and Bouwer (1989) and the type-curve-matching method for unconfined aquifers presented in Butler (1997). However, as discussed in Spane and Newcomer (2004), the standard typecurve analysis method provides more accurate, representative analytical results and does not have any of the inherent analytical weaknesses that are characteristic of the Bouwer and Rice method. For this reason, hydraulic-property estimates for test zones exhibiting over-damped response behavior at well 399-3-21 are based solely on the standard type-curve analysis method.

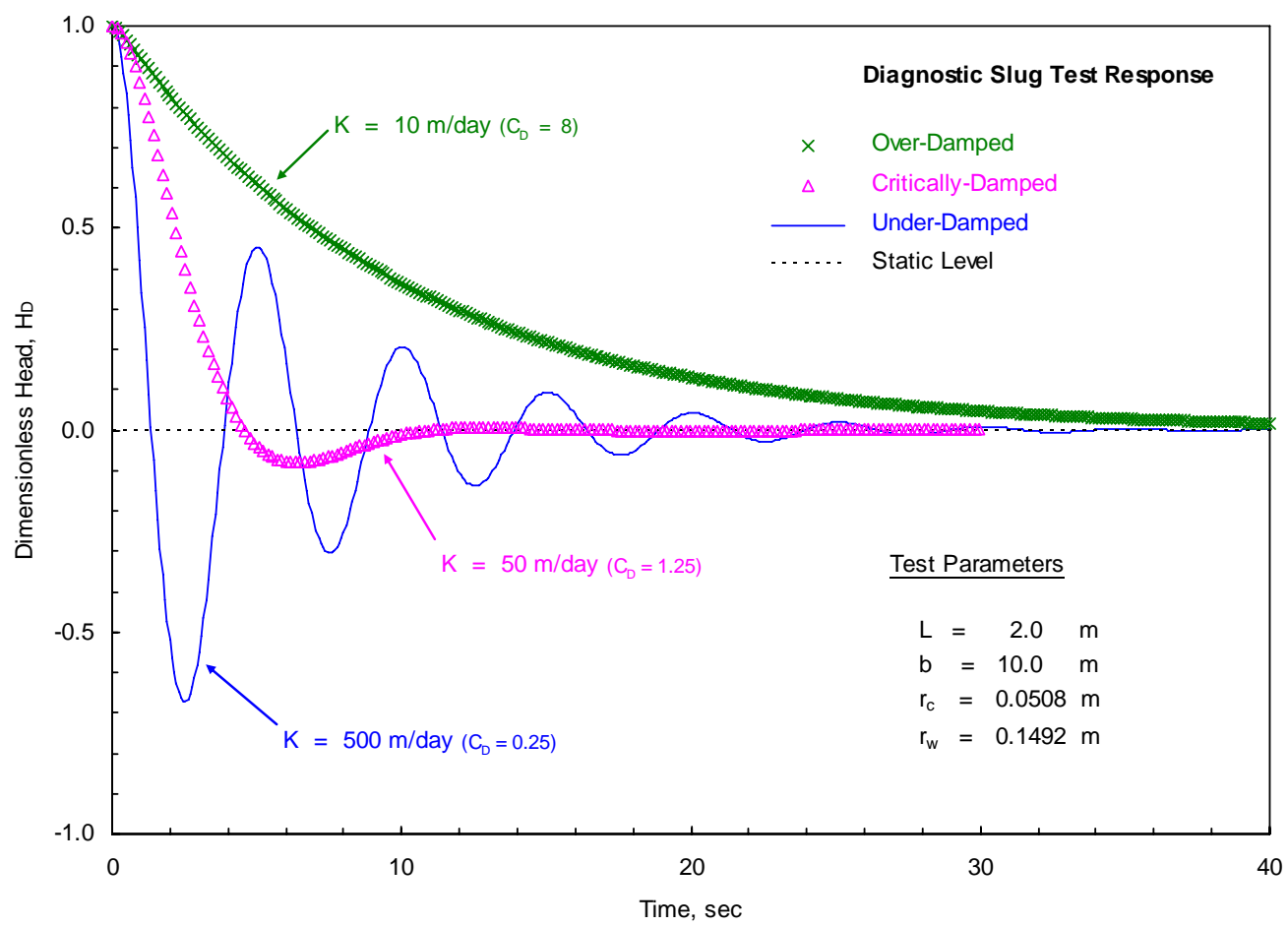

Figure 4.1. Diagnostic Slug Test Response (for $\sim$ Well 399-3-21 test conditions)

Under-damped (oscillatory) test-response patterns are exhibited within stress wells where inertial forces are predominant over formation frictional forces. This commonly occurs in wells with extremely long fluid columns (i.e., large water mass within the well column) and/or that penetrate highly permeable aquifers (e.g., Hanford formation). Tests exhibiting under-damped behavior should be conducted with very small stress-level applications and with the pressure sensor located near the top of the fluid column. Only the top test/depth interval (Zone 1A) exhibited under-damped behavior. Under-damped slug test responses are influenced by processes (e.g., inertial) that are not accounted for in the previously discussed slug test analytical methods (i.e., for over-damped tests). Because of this, slug tests exhibiting these response characteristics cannot be analyzed quantitatively using the Bouwer and Rice or standard typecurve methods. High-K analysis methods that can be employed for analyzing unconfined aquifer tests exhibiting either under-damped or critically damped response behavior include those described in Springer and Gelhar (1991), Butler (1997), McElwee and Zenner (1998), McElwee (2001), Butler and Garnett (2000), and Zurbuchen et al. (2002). Because of the ease provided by a spreadsheet-based 
approach, the test-analysis method presented in Butler and Garnett (2000) was used for analyzing the Zone 1A slug test responses. A detailed discussion of this analytical procedure and method is presented in Spane and Newcomer (2004).

As mentioned previously, critically damped test responses are indicated by stress well water-level responses that are transitional to the over- and under-damped test conditions, as shown in Figure 4.1. They typically occur in wells that monitor test formations exhibiting intermediate to high hydraulic conductivity. As noted in Butler (1997), distinguishing between over- and critically damped slug test response may be difficult in some cases (i.e., due to test signal noise) when examined on arithmetic response plots. Proper model identification may be enhanced, however, when diagnostic semi-log plots are used, i.e., log head versus time (e.g., Bouwer and Rice plot). Critically damped slug tests exhibit a diagnostic concave-downward pattern when plotted in this semi-log plot format. This is in contrast to over-damped response behavior, which displays either a linear or concave upward (elastic) pattern. Because critically damped slug test responses are influenced by inertial processes, they (like underdamped slug tests) must use appropriate analytical methods that take these processes into account, e.g., High-K analysis methods. However, no well 399-3-21 test zones exhibited critically damped response behavior. 


\subsection{Slug Test Results}

The following discussion presents pertinent information describing slug testing activities and analysis results for the test/depth zones that were hydrologically characterized at the 300-Area/VOC well 399-3-21, as it was advanced to its final completion depth. Table S.1 presents pertinent slug test information for the respective test/depth intervals, while Table S.2 summarizes the slug test analysis results. The borehole log for well 399-3-21 is presented in Appendix A, which can be referred to for a geologic description of the respective well test zone/depth intervals.

In all, eight specific depth intervals were tested between April 18 and May 7, 2007 using multiple slug test characterizations as the borehole was advanced to its final depth of $45.7 \mathrm{~m}$ bgs. Complications were experienced during the testing of two of the depth intervals (Tables S.1 and S.2; Zones 1B and 2B), which eliminated the possibility of characterizing these test intervals. Analysis of the slug test results for the six successfully tested depth intervals indicates a relatively narrow-range for test zones within the Ringold Formation ranging between 0.27 and $2.03 \mathrm{~m} /$ day. The well 399-3-21 values fall within the lower range ( 0.04 to $41.2 \mathrm{~m}$ /day; geometric mean $=2.38 \mathrm{~m} /$ day) for 10 other Ringold Formation test/depth intervals recently obtained from test-characterization boreholes in the 300-Area, as reported in Williams et al. (2007).

One high-permeability Hanford formation test/depth interval at well 399-3-21 (Zone 1A) provided a permeability estimate of $568 \mathrm{~m} /$ day. This estimate value falls within the general range of $>100 \mathrm{~m} /$ day to $>2,000 \mathrm{~m} /$ day previously reported by Williams et al. (2007) for this hydrogeologic unit, which is based on recent 300-Area slug test characterizations.

The hydraulic conductivity vertical-depth profile for well 399-3-21, which is based on the test/depth interval slug test characterization, is shown in Figure S.2(a). For comparison purposes, the hydraulic conductivity profile for adjacent well 399-3-20 is also presented in Figure S.2(b). In comparing the two depth profiles, it is interesting to note that a significant difference in hydraulic conductivity estimates (i.e., 1.04 versus $33.4 \mathrm{~m} /$ day) is exhibited for an overlapping Ringold Formation test/depth interval at well 3993-21 (Zone 2A; 25.88 to 27.28 m) and adjacent well 399-3-20 (Zone D; 25.30 to $27.58 \mathrm{~m}$ ), respectively; note: the lateral well distance separation $=6.30 \mathrm{~m}$. Currently, it is not known whether the exhibited difference in hydraulic conductivity values is real (i.e., reflective of lateral heterogeneity within the Ringold Formation) or whether the test results for this depth zone at well 399-3-20 are biased by possible hydraulic communication with the overlying Hanford formation unit (i.e., due to unrecognized drill casing bypass during testing). It is interesting to note, however, that hydraulic communication with the overlying Hanford formation unit was detected during testing of Zone 2B at well 399-3-21, which also encompasses this test/depth interval.

A brief description of the individual depth interval (Zone) tests is presented below. Selected analysis figures for the respective test zones are presented for Figures 5.1 through 5.6. 


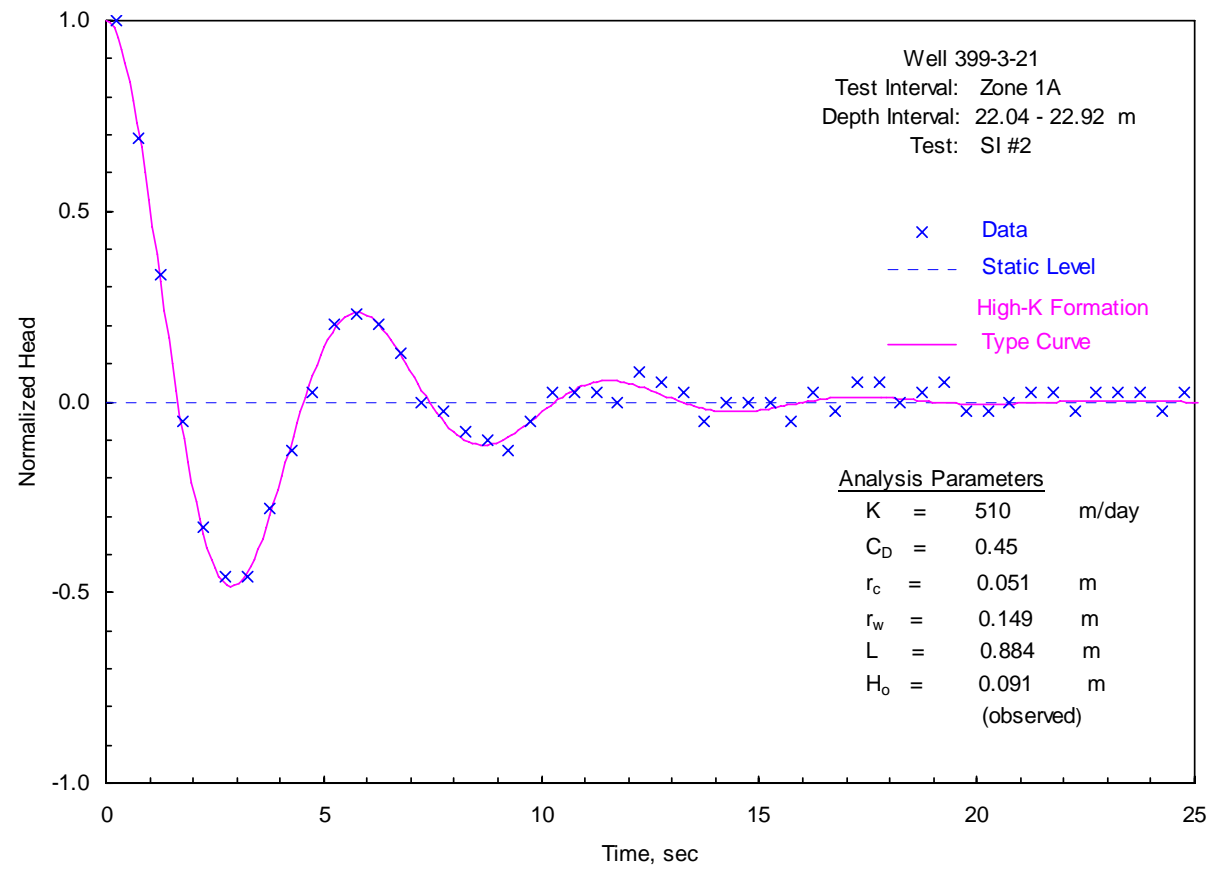

Figure 5.1. Selected High-K Type-Curve Analysis Plot: Well 399-3-21; Test Zone 1A, Test SI \#2

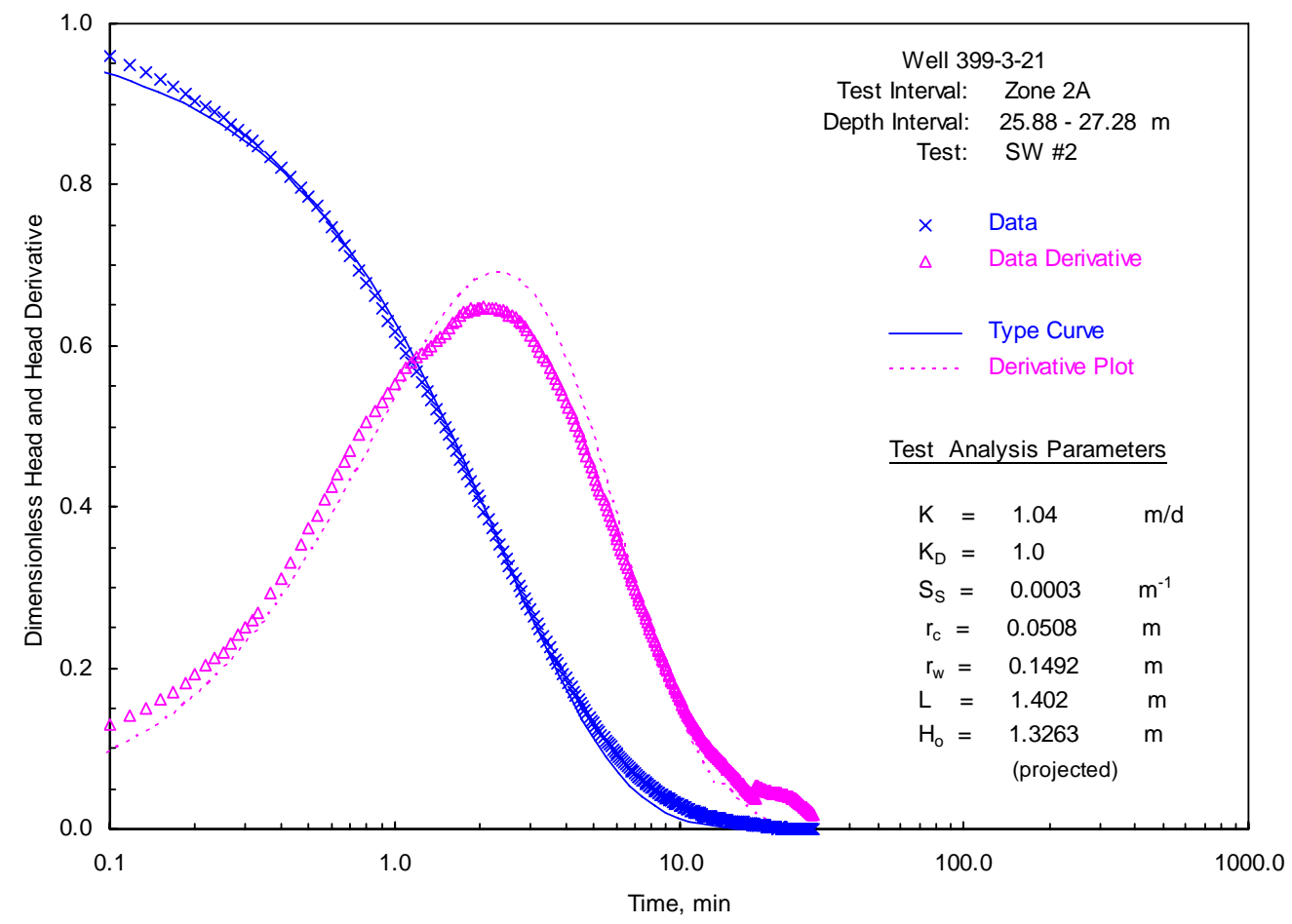

Figure 5.2. Selected Type-Curve Analysis Plot: Well 399-3-21; Test Zone 2A, Test SW \#2 


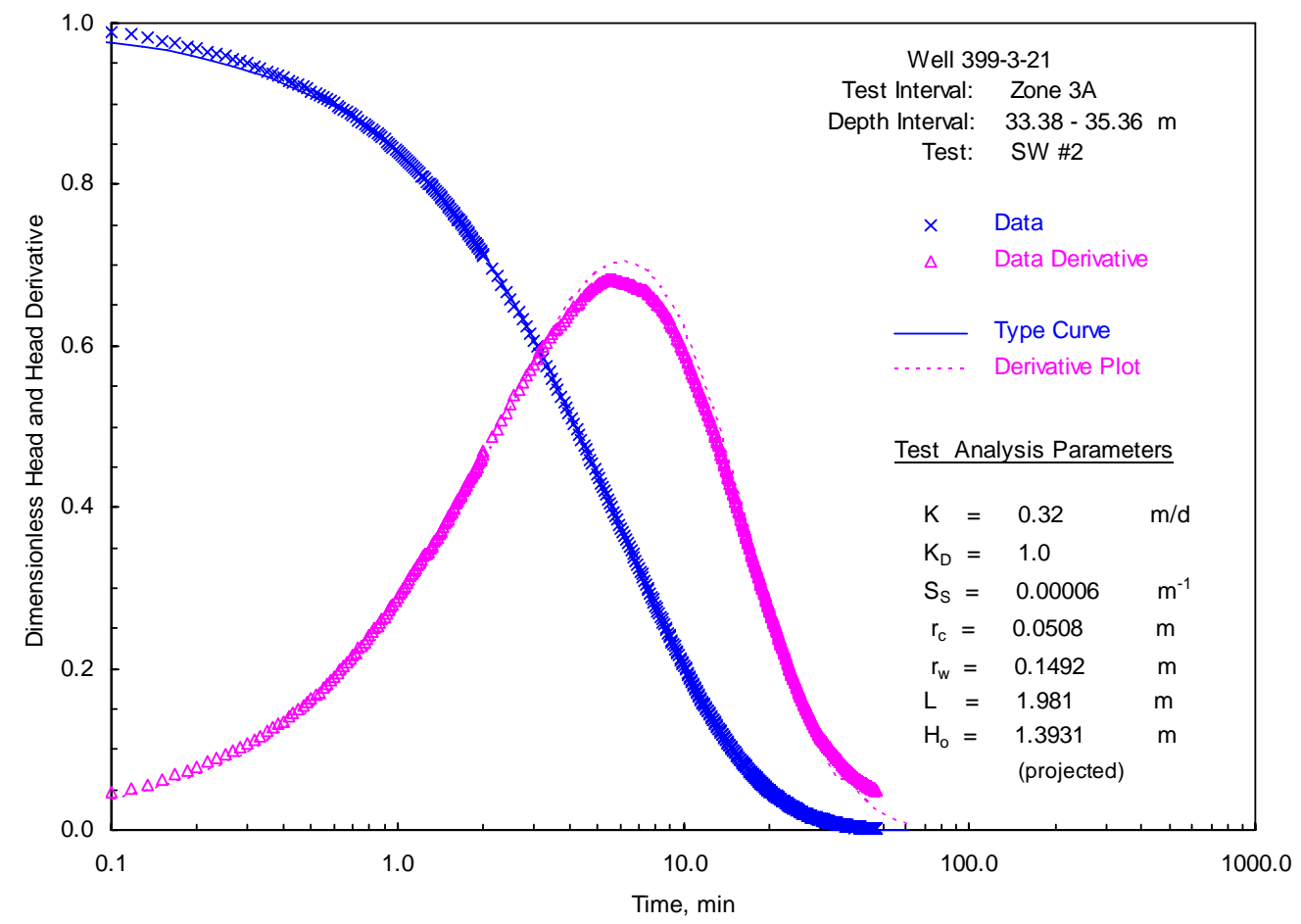

Figure 5.3. Selected Type-Curve Analysis Plot: Well 399-3-21; Test Zone 3A, Test SW \#2

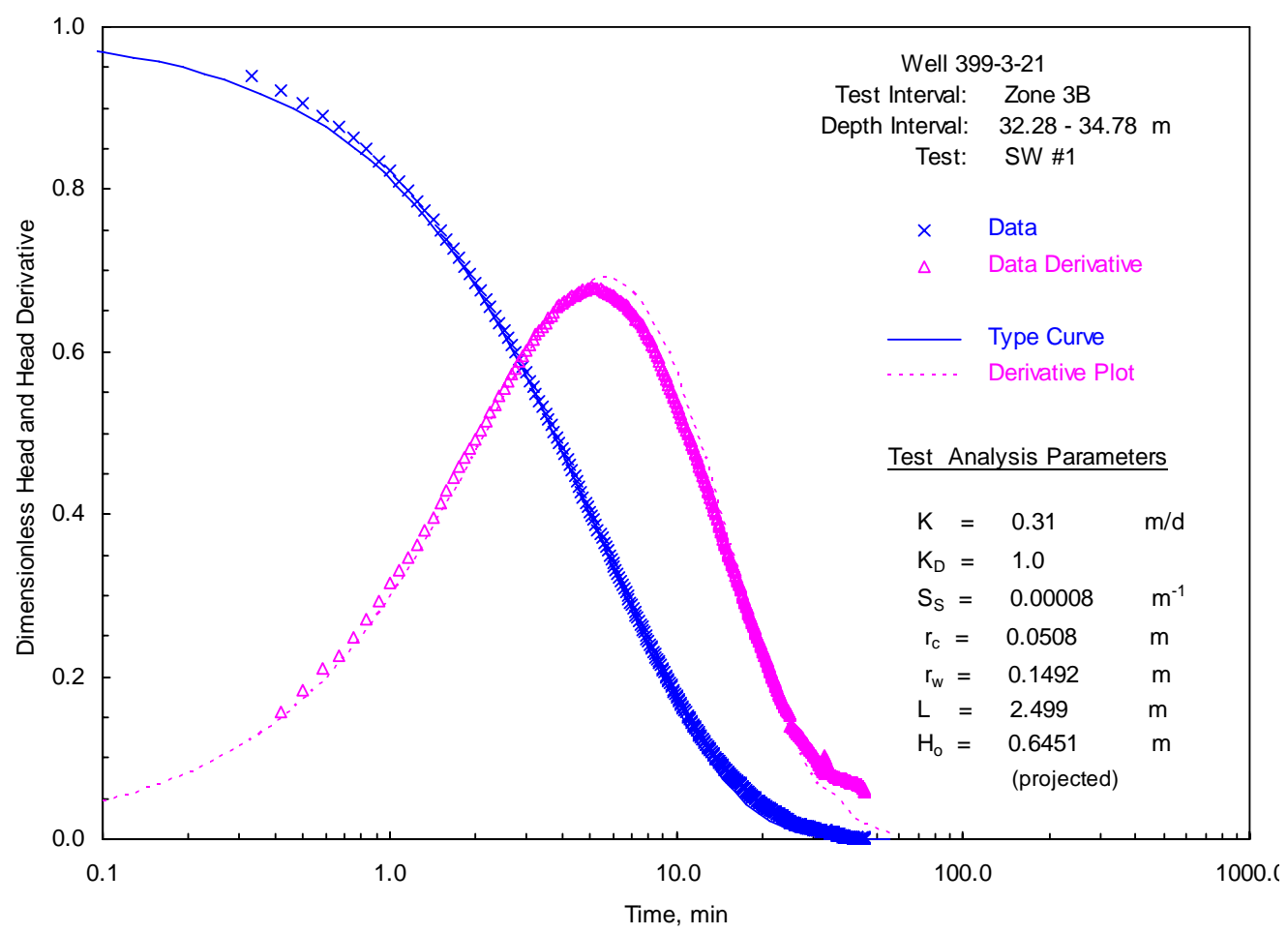

Figure 5.4. Selected Type-Curve Analysis Plot: Well 399-3-21; Depth Zone 3B, Test SW \#1 


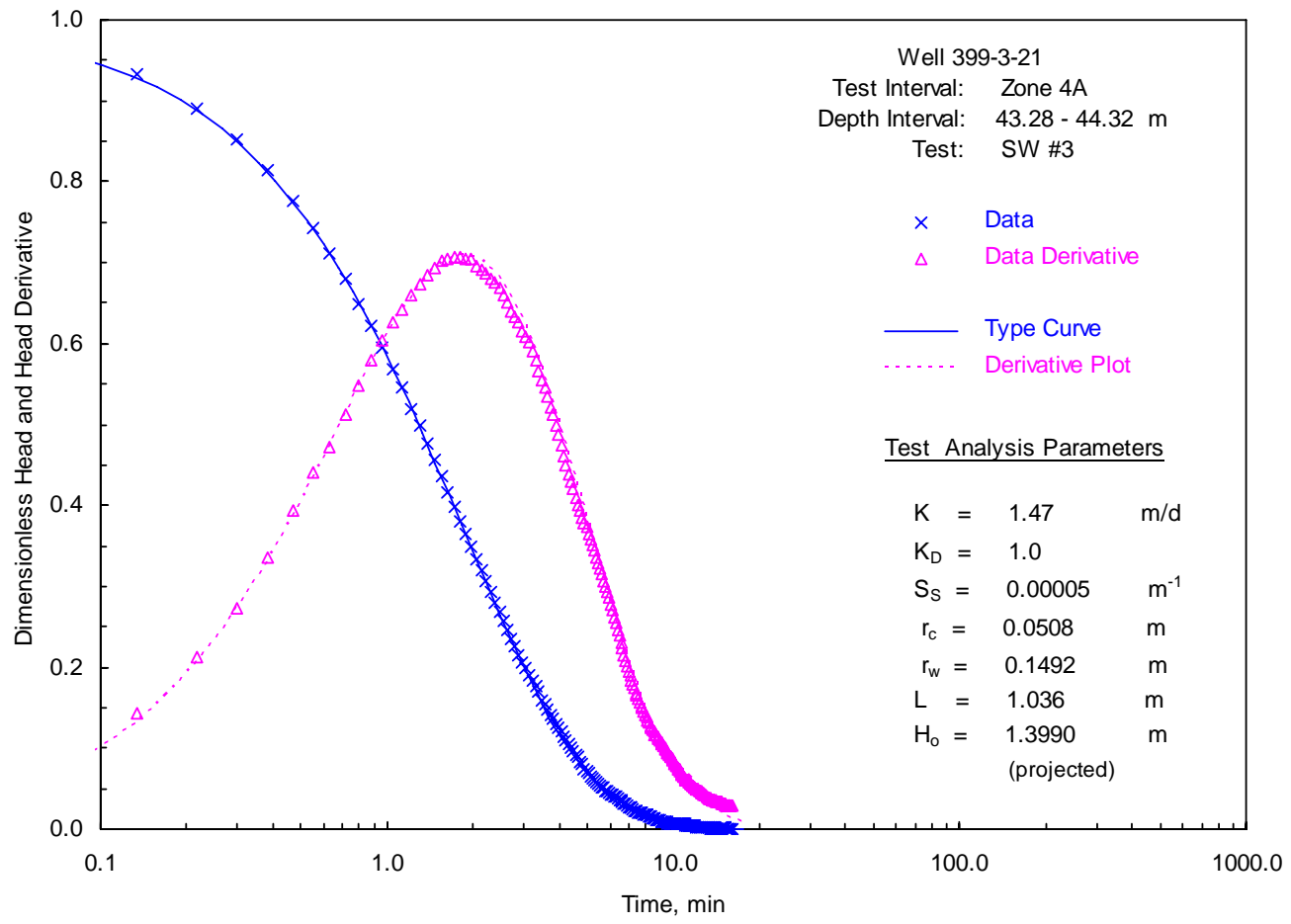

Figure 5.5. Selected Type-Curve Analysis Plot: Well 399-3-21; Depth Zone 4A, Test SW \#3

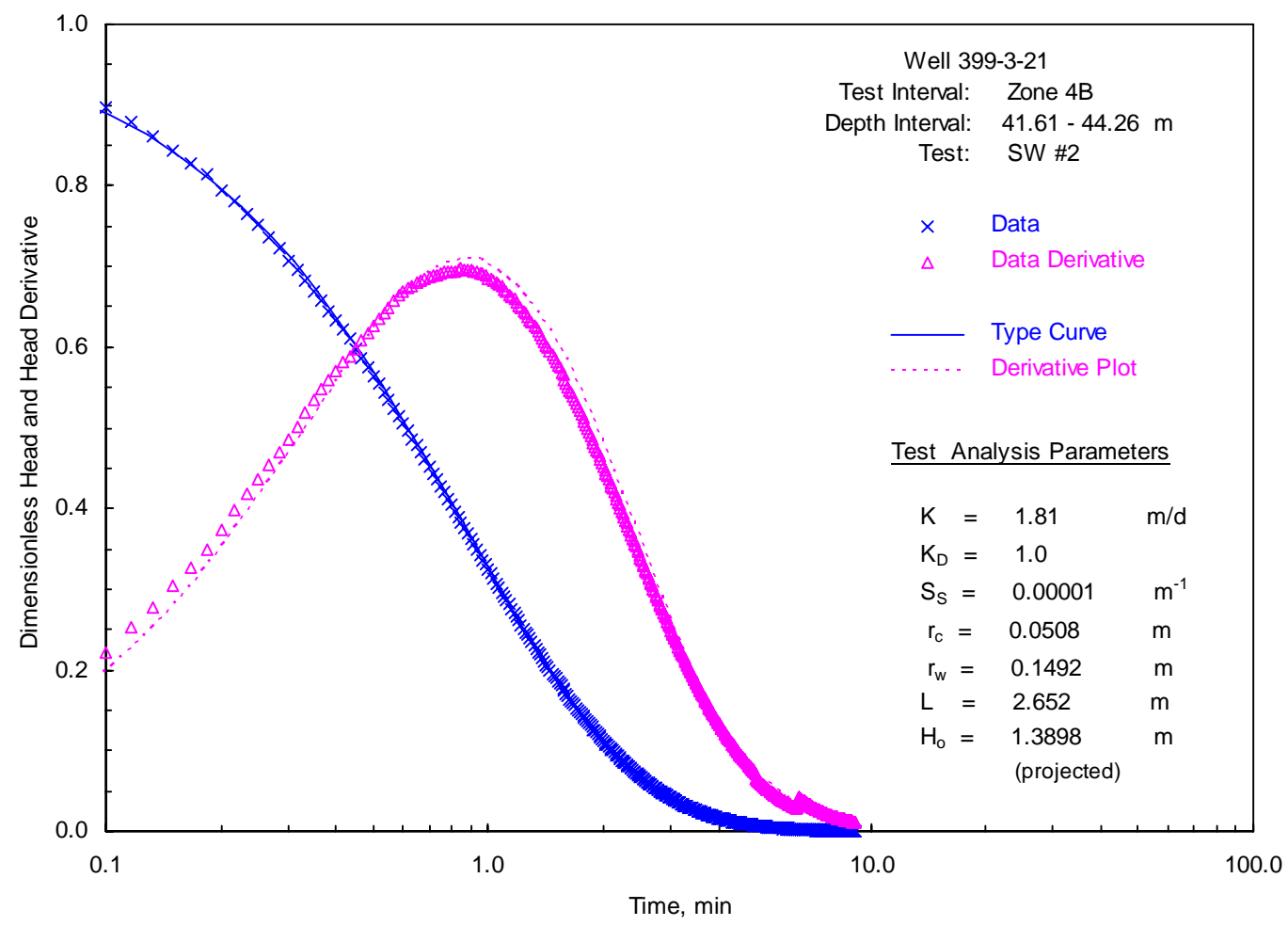

Figure 5.6. Selected Type-Curve Analysis Plot: Well 399-3-21; Depth Zone 4B, Test SW \#2 


\subsection{Zone 1A (Depth: 22.04 to $22.92 \mathrm{~m}$ )}

After reaching a depth of $22.92 \mathrm{~m}$ bgs, the packer/well-screen assembly was lowered to the bottom of the borehole and the $0.298 \mathrm{~m}$ O.D. drill casing retracted $0.88 \mathrm{~m}$, producing a test/depth interval for Zone $1 \mathrm{~A}$ of 22.04 to $22.92 \mathrm{~m}$ bgs. The borehole geology log indicates that sediments within the test interval can be categorized as a poorly-sorted, unconsolidated sandy gravel, which consists of $\sim 80 \%$ gravel and $\sim 20 \%$ medium-to-coarse angular sand (Appendix A). At the time of testing, the well-screen test interval was located approximately $7.6 \mathrm{~m}$ below the unconfined aquifer water-table surface, and test results are reflective of sediments within the Hanford formation (Unit 1).

A series of four slug-injection and four slug-withdrawal tests were conducted between 0906 hours and 1147 hours (PST), April 18, 2007. The static depth-to-water for the test interval during testing was $14.48 \mathrm{~m}$ bgs. The slug tests were conducted with two different-sized slugging rods. The stress levels for the two slugging rods are calculated to impose a slug test response of $0.89 \mathrm{~m}$ (low-stress tests) and $1.39 \mathrm{~m}$ (high-stress tests) within a 0.1016-m inside diameter test string that was used to install the packer/wellscreen assembly. All slug tests exhibited under-damped (oscillatory response) behavior, which is indicative of high-permeability test-zone conditions. As noted in Section 4, slug tests exhibiting this type of response behavior cannot be analyzed using standard, over-damped-response based analytical methods (i.e., using either the Bouwer and Rice or type-curve methods). The High-K analysis method presented in Butler and Garnett (2000) and Butler et al. (2003) was used to analyze the slug tests for Zone 1A at well 399-3-21 that exhibit under-damped response characteristics. As discussed in Butler et al. (2003), for tests conducted in high-permeability formations, the pressure sensor should be situated in close proximity to the top of the well water-column to avoid well-acceleration effects. For most of the slug tests analyzed for this test zone, the pressure sensor was situated within 0.5 meters of the top of the well water-column. No significant difference in test response (or analytical results), however, was exhibited for tests where the pressure probe was located at a greater distance below the well water-column (i.e., probe depth $=\sim 2 \mathrm{~m}$ ).

Figure 5.1 shows the results of a High-K analysis plot for one of the tests analyzed for this test zone. As indicated, an under-damped (oscillatory) response is exhibited with a rapidly damped recovery to static conditions (i.e., recovery within $\sim 30$ seconds). Similar response characteristics were exhibited for the other Zone 1A tests. Estimates for K ranged between 510 and $625 \mathrm{~m}$ /day and averaged $568 \mathrm{~m} /$ day for this test zone.

\subsection{Zone 1B (Depth: 21.09 to $22.92 \mathrm{~m}$ )}

After slug test characterization activities were completed for Zone 1A, the 0.298-m O.D. drill casing was retracted an additional $0.95 \mathrm{~m}$, producing a test/depth interval for Zone 1B of 21.09- to 22.92-m bgs (total test interval length $=1.83 \mathrm{~m}$ ). The borehole geology log indicates the same material within the newly exposed test section as exhibited within Zone 1A, with the sediments within the test interval being categorized as a poorly sorted, unconsolidated sandy gravel, which consists of $\sim 80 \%$ gravel and $\sim 20 \%$ medium-to-coarse angular sand (Appendix A). At the time of testing, the well-screen test interval was located approximately $6.6 \mathrm{~m}$ below the unconfined aquifer water-table surface, and test results are also reflective of sediments within the Hanford formation (Unit 1). 
A series of three slug withdrawal tests were attempted between 1335 hours and 1420 hours (PST), April 18, 2007. The static depth-to-water for the test interval during testing was $14.48-\mathrm{m}$ bgs. The slug tests were conducted with only the larger-sized slugging rod, which is calculated to impose a slug test response of $1.39 \mathrm{~m}$ (high-stress tests) within a 0.1016-m inside diameter test-string assembly. Based on test response and observed field conditions, the slug tests performed for Zone 1B were adversely affected by well-screen plugging by fine-grained sediments. It is interesting to note that the Borehole Log (Appendix A) indicates at a depth of $~ 20.4 \mathrm{~m}$ “...a thin layer of fine to coarse sand...," which exhibited "heaving” conditions. This zone directly overlies the Zone 1B test interval and may have contributed the incursions of plugging sediments observed within the well-screen. Because of this non-formational test condition, no representative hydraulic-property estimates were determined for this test-zone interval.

\subsection{Zone 2A (Depth: 25.88 to $27.28 \mathrm{~m}$ )}

After reaching a depth of 27.28-m bgs, the packer/well-screen assembly was lowered to the bottom of the borehole and the $0.298-\mathrm{m}$ O.D. drill casing retracted $1.40 \mathrm{~m}$, producing a test/depth interval for Zone 2A of 25.88- to 27.28-m bgs. The borehole geology log indicates that sediments within the test interval can be categorized as a well-sorted, well-to-moderately-consolidated, fine-to-medium coarse sand (Appendix A). At the time of testing, the well-screen test interval was located approximately $11.5 \mathrm{~m}$ below the unconfined aquifer water-table surface, and test results are reflective of a fine-grained sediment unit within the Ringold Formation (Unit 5).

A series of four slug withdrawal tests were conducted between 0848 hours and 1305 hours (PST), April 23, 2007. The static depth-to-water for the test interval during testing was 14.39-m bgs. The slug tests were conducted with two different-sized slugging rods. The stress levels for the two slugging rods are calculated to impose a slug test response of $0.63 \mathrm{~m}$ (low-stress tests) and $1.39 \mathrm{~m}$ (high-stress tests) within a 0.1016-m inside-diameter test string that was used to install the packer/well-screen assembly. All slug tests exhibited elastic, over-damped (exponential-decay response) behavior, which is indicative of low-tomoderate permeability test-zone conditions. A comparison of the normalized, higher and lower stress, slug test responses indicated identical behavior, suggesting linear test-response characteristics. Slug tests exhibiting this type of response behavior can be analyzed quantitatively using homogeneous formation analysis approaches, as described in Butler (1997). For the homogeneous formation analysis, the standard type-curve method provided identical estimates for $\mathrm{K}$ and Ss for all tests of $1.04 \mathrm{~m} /$ day and 3.0E-4 m-1, respectively. A test example with an analysis plot for the Zone 2A test interval is shown in Figure 5.2.

\subsection{Zone 2B (Depth: 24.96 to $27.28 \mathrm{~m}$ )}

After slug test characterization activities were completed for Zone 2A, the 0.298-m O.D. drill casing was retracted an additional $0.82 \mathrm{~m}$, producing a test/depth interval for Zone 2B of 24.96 to 27.28-m bgs (total test interval length $=2.32 \mathrm{~m}$ ). The borehole geology log indicates the same material within the newly exposed test section as exhibited within Zone 2A, with the sediments within the test interval being categorized as a well-sorted, well-to-moderately-consolidated, fine-to-medium-coarse sand (Appendix A). At the time of testing, the well-screen test interval was located approximately $10.6 \mathrm{~m}$ below the unconfined aquifer water-table surface, and test results are also reflective of a fine-grained sediment unit within the Ringold Formation (Unit 5). 
A series of four slug injection and four slug withdrawal tests were attempted between 1347 hours and 1539 hours (PST), April 23, 2007. The static depth-to-water for the test interval during testing was $14.39-\mathrm{m}$ bgs. The slug tests were conducted with two different-sized slugging rods. The stress levels for the two slugging rods are calculated to impose a slug test response of $0.63 \mathrm{~m}$ (low-stress tests) and $1.39 \mathrm{~m}$ (high-stress tests) within a 0.1016-m inside diameter test string that was used to install the packer/wellscreen assembly. No consistent or uniform test-response characteristics were demonstrated for the sequence of slug tests conducted for the Zone 2B test interval. The later slug tests exhibited progressively faster early-time recovery that transitioned to a slower recovery pattern. This type of test response is indicative of a near-well heterogeneity, such as vertical flow along the drill casing during testing. Because of this non-formational test condition, no representative hydraulic-property estimates were determined for this test zone.

\subsection{Zone 3A (Depth: 33.38 to $35.36 \mathrm{~m}$ )}

After reaching a depth of $35.36 \mathrm{~m}$ bgs, the packer/well-screen assembly was lowered to the bottom of the borehole and the $0.298-\mathrm{m}$ O.D. drill casing retracted $1.98 \mathrm{~m}$, producing a test/depth interval for Zone 3A of 33.38- to 35.36-m bgs. The borehole geology log indicates that sediments within the test interval can be categorized as a well-consolidated, silty, sandy gravel consisting of 50 to $70 \%$ sand, 20 to $30 \%$ pebble gravel, and 10 to $20 \%$ silt (Appendix A). At the time of testing, the well-screen test interval was located approximately $19.0 \mathrm{~m}$ below the unconfined aquifer water-table surface, and test results are reflective of sedimentary units within the Ringold Formation (Unit 5).

A series of four slug withdrawal tests were conducted between 1459 hours and 1635 hours (PST), April 30, 2007, and between 0649 hours and 0753 hours, May 1, 2007. The static depth-to-water for the test interval during testing was $14.39-\mathrm{m}$ bgs. The slug tests were conducted with two different-sized slugging rods. The stress levels for the two slugging rods are calculated to impose a slug test response of $0.63 \mathrm{~m}$ (low-stress tests) and $1.39 \mathrm{~m}$ (high-stress tests) within a 0.1016-m inside diameter test string that was used to install the packer/well-screen assembly. All slug tests exhibited over-damped (exponential-decay response) behavior, which is indicative of low-permeability test-zone conditions. A comparison of the normalized, higher and lower stress, slug test responses indicated nearly identical behavior, suggesting linear test-response characteristics. Slug tests exhibiting this type of response behavior can be analyzed quantitatively using homogeneous-formation analysis approaches, as described in Butler (1997). For the homogeneous-formation analysis, the standard type-curve method provided nearly identical estimates for $\mathrm{K}$ ranging between 0.32 and $0.36 \mathrm{~m} /$ day, and averaging $0.34 \mathrm{~m} /$ day. An identical type-curve analysis value for Ss of $6.0 \mathrm{E}-5 \mathrm{~m}-1$ was indicated for all tests. A test example with analysis plot for the Zone $3 \mathrm{~A}$ test interval is shown in Figure 5.3.

\subsection{Zone 3B (Depth: 32.28 to $34.78 \mathrm{~m}$ )}

After slug test characterization activities were completed for Zone 3A, the 0.298-m O.D. drill casing was retracted an additional $1.10 \mathrm{~m}$ on May 1, 2007. A small amount of sediment infilling within the inside of the well screen occurred during the drilling casing retraction, which reduced the test/depth interval for Zone 3B to 32.28- to 34.78-m bgs (total test interval length $=2.50 \mathrm{~m}$ ). The borehole geology log indicates the same material within the newly exposed test section as exhibited within Zone 3A, with the sediments within the test interval being categorized as a well-consolidated, silty, sandy gravel consisting of 50 to $70 \%$ sand, 20 to 30\% pebble gravel, and 10 to 20\% silt (Appendix A). At the time of testing, the 
well-screen test interval was located approximately $19.0 \mathrm{~m}$ below the unconfined aquifer water-table surface, and test results are reflective of sedimentary units within the Ringold Formation (Unit 5).

A series of four slug-injection and four slug-withdrawal tests were conducted between 0939 hours and 1435 hours (PST), May 1, 2007. The static depth-to-water for the test interval during testing was 14.40 -m bgs. The slug tests were conducted with two different-sized slugging rods. The stress levels for the two slugging rods are calculated to impose a slug test response of $0.63 \mathrm{~m}$ (low-stress tests) and $1.39 \mathrm{~m}$ (high-stress tests) within a 0.1016-m inside diameter test string that was used to install the packer/wellscreen assembly. All slug tests exhibited over-damped (exponential-decay response) behavior, which is indicative of low-permeability test-zone conditions. A comparison of the normalized, higher and lower stress, slug test responses indicated identical behavior, suggesting linear test-response characteristics. Slug tests exhibiting this type of response behavior can be analyzed quantitatively using homogeneous formation-analysis approaches, as described in Butler (1997). For the homogeneous-formation analysis, the standard type-curve method provided identical estimates for $\mathrm{K}$ and Ss for all tests of $0.31 \mathrm{~m} / \mathrm{day}$ and 8.0E-5 m-1, respectively. A test example with analysis plot for the Zone 3B test interval is shown in Figure 5.4.

\subsection{Zone 4A (Depth: 43.28 to $44.32 \mathrm{~m}$ )}

After reaching a depth of 44.32-m bgs, the packer/well-screen assembly was lowered to the bottom of the borehole and the $0.298-\mathrm{m}$ O.D. drill casing retracted $1.04 \mathrm{~m}$, producing a test/depth interval for Zone 4A of 43.28- to 44.32-m bgs. The borehole geology log provides the same geologic description as for the overlying Zones 3A and 3B, which indicates that sediments within this test interval can be categorized as a well-consolidated, silty, sandy gravel consisting of 50 to $70 \%$ sand, 20 to 30\% pebble gravel, and 10 to $20 \%$ silt (Appendix A). At the time of testing, the well-screen test interval was located approximately $29.1 \mathrm{~m}$ below the unconfined aquifer water-table surface, and test results are reflective of sedimentary units within the Ringold Formation (Unit 5).

A series of four slug-injection and four slug-withdrawal tests were conducted between 0805 hours and 1635 hours (PST), May 4, 2007. The static depth-to-water for the test interval during testing was $14.23-\mathrm{m}$ bgs. The slug tests were conducted with two different-sized slugging rods. The stress levels for the two slugging rods are calculated to impose a slug test response of $0.63 \mathrm{~m}$ (low-stress tests) and $1.39 \mathrm{~m}$ (high-stress tests) within a 0.1016-m inside diameter test string that was used to install the packer/wellscreen assembly. All slug tests exhibited over-damped (exponential-decay response) behavior, which is indicative of low-to-moderate permeability test-zone conditions. A comparison of the normalized, higher and lower stress, slug test responses indicated identical behavior, suggesting linear test-response characteristics. Slug tests exhibiting this type of response behavior can be analyzed quantitatively using homogeneous formation analysis approaches, as described in Butler (1997). For the homogeneous formation analysis, the standard type-curve method provided identical estimates for $\mathrm{K}$ and Ss for all tests of $1.47 \mathrm{~m} /$ day and $5.0 \mathrm{E}-5 \mathrm{~m}-1$, respectively. A test example with analysis plot for the Zone $4 \mathrm{~A}$ test interval is shown in Figure 5.5.

\subsection{Zone 4B (Depth: 41.61 to $44.26 \mathrm{~m}$ )}

After slug test characterization activities were completed for Zone 4A, the 0.298-m O.D. drill casing was retracted an additional $1.67 \mathrm{~m}$ on May 7, 2007. A small amount of sediment infilling within the inside of 
the well screen occurred during the drilling-casing retraction, which reduced the test/depth interval for Zone 4B to 41.61- to 44.26-m bgs (total test interval length $=2.65 \mathrm{~m}$ ). The borehole geology log indicates the same material within the newly exposed test section as exhibited within Zone 4A, with the sediments within the test interval being categorized as a well-consolidated, silty, sandy gravel consisting of 50 to $70 \%$ sand, 20 to 30\% pebble gravel, and 10 to 20\% silt (Appendix A). At the time of testing, the well-screen test interval was located approximately $27.5 \mathrm{~m}$ below the unconfined aquifer water-table surface, and test results are reflective of sedimentary units within the Ringold Formation (Unit 5).

A series of three slug-injection and three slug-withdrawal tests were conducted between 0658 hours and 0842 hours (PST), May 7, 2007. The static depth-to-water for the test interval during testing was 14.16-m bgs. The slug tests were conducted with two different-sized slugging rods. The stress levels for the two slugging rods are calculated to impose a slug test response of $0.63 \mathrm{~m}$ (low-stress tests) and $1.39 \mathrm{~m}$ (high-stress tests) within a 0.1016-m inside diameter test string that was used to install the packer/wellscreen assembly. All slug tests exhibited over-damped (exponential-decay response) behavior, which is indicative of low-permeability test-zone conditions. A comparison of the normalized, higher and lower stress, slug test responses indicated identical behavior, suggesting linear test-response characteristics. Slug tests exhibiting this type of response behavior can be analyzed quantitatively using homogeneousformation analysis approaches, as described in Butler (1997). For the homogeneous-formation analysis, the standard type-curve method provided identical estimates for $\mathrm{K}$ and Ss for all tests of $1.81 \mathrm{~m} / \mathrm{day}$ and $1.0 \mathrm{E}-5 \mathrm{~m}-1$, respectively. A test example with an analysis plot for the Zone 4B test interval is shown in Figure 5.6. 


\subsection{Hydraulic Conductivity Depth Profile}

Figure S.2(a) shows a depth profile of the vertical distribution of hydraulic conductivity values determined from slug tests conducted at well 399-3-21. The distribution is based on the test/depth testcharacterization results that are summarized in Tables S.1, S.2, and 5.1. As indicated in Table 5.1, the hydraulic conductivity for depth intervals 32.28 to $33.38 \mathrm{~m}$ and 41.61 to $43.28 \mathrm{~m}$ were determined based on the principle of de-superposition, which, generally stated, indicates that within linear-based groundwater systems (e.g., confined aquifers), the overall composite transmissivity of a large test interval is the summation of hydraulic conductivity times the thickness of its contributing parts. If a test section is a subset of an overall larger test interval, its transmissivity can be subtracted from the encompassing, larger test section, and the residual transmissivity is assigned to the encompassing interval. It should be noted that the unconfined aquifer test conditions at well 399-3-21 are expected to behave mainly in linearsystem fashion because of the test-zones depth relationship within the aquifer and lack of influence of unconfined aquifer delayed-yield effects on slug test-response characteristics.

For comparison purposes, the hydraulic-conductivity depth profile for adjacent well 399-3-20 is also presented in Figure S.2(b). In comparing the two depth profiles, it is interesting to note that a significant difference in hydraulic conductivity estimates (i.e., 1.04 versus $33.4 \mathrm{~m} /$ day) is exhibited for an overlapping Ringold Formation test/depth interval at well 399-3-21 (Zone 2A; 25.88 to $27.28 \mathrm{~m}$ ) and adjacent well 399-3-20 (Zone D; 25.30 to $27.58 \mathrm{~m}$ ), respectively; note: the lateral well distance separation = $6.30 \mathrm{~m}$. Currently, it is not known whether the exhibited difference in hydraulic-conductivity values is real (i.e., reflective of lateral heterogeneity within the Ringold Formation) or whether the test results for this depth zone at well 399-3-20 are biased by possible hydraulic communication with the overlying Hanford-formation unit (i.e., due to unrecognized drill casing bypass during testing). It is interesting to note, however, that hydraulic communication with the overlying Hanford-formation unit was detected during testing of Zone 2B at well 399-3-21, which also encompasses this test/depth interval. 
Table 6.1. Vertical Hydraulic Conductivity Distribution at Well 399-3-21, Based on Discrete Depth Interval Slug Test Results

\begin{tabular}{|c|c|c|c|}
\hline \multirow[b]{2}{*}{$\begin{array}{c}\text { Test/Depth } \\
\text { Interval } \\
\text { m, bgs } \\
\end{array}$} & \multicolumn{2}{|c|}{ Best Estimate Value } & \multirow[b]{2}{*}{ Basis/Comments } \\
\hline & $\begin{array}{c}\text { Hydraulic Conductivity, } \\
\mathbf{K}_{\mathbf{h}} \text { (a) } \\
(\mathbf{m} / \text { day) }\end{array}$ & $\begin{array}{c}\text { Specific Storage, } \\
\mathrm{S}_{\mathrm{s}}\left(\mathbf{m}^{-1}\right)\end{array}$ & \\
\hline $22.04-22.92$ & 568 & NA & Zone 1A \\
\hline $25.88-27.28$ & 1.04 & $3.0 \mathrm{E}-4$ & Zone 2A \\
\hline 32.28 - 33.38* & $0.27 *$ & $6.0 \mathrm{E}-5-8.0 \mathrm{E}-5$ & Zone 3B - Zone 3A \\
\hline 33.38 - 35.36 & 0.34 & $6.0 \mathrm{E}-5$ & Zone 3A \\
\hline $41.61-43.28 *$ & $2.03^{*}$ & $1.0 \mathrm{E}-5-5.0 \mathrm{E}-5$ & Zone 4B - Zone 4A \\
\hline $43.28-44.32$ & 1.47 & $5.0 \mathrm{E}-5$ & Zone 4A \\
\hline \multicolumn{4}{|c|}{$\begin{array}{l}\text { (a) Assumed to be uniform within the test/depth interval . } \\
\text { * Based on principle of de-superposition by subtracting the transmissivity value for an enclosed } \\
\text { test/depth interval from the encompassing test/depth interval and assigning residual to remaining test } \\
\text { zone }\end{array}$} \\
\hline
\end{tabular}




\subsection{References}

Bouwer H. 1989. “The Bouwer and Rice slug test - an update.” Ground Water 27(3):304-309.

Bouwer H, and RC Rice. 1976. “A slug test for determining hydraulic conductivity of unconfined aquifers with completely or partially penetrating wells.” Water Resources Research 12(3):423-428.

Butler JJ, Jr. 1997. The design, performance, and analysis of slug tests. Lewis Publishers, CRC Press, Boca Raton, Florida. .

Butler JJ, Jr., and EJ Garnett. 2000. Simple procedures for analysis of slug tests in formations of high hydraulic conductivity using spreadsheet and Scientific Graphics Software. Open-file Report 2000-40, Kansas Geological Survey, Lawrence, Kansas.

Butler JJ, Jr., EJ Garnett, and JM Healey. 2003. “Analysis of slug tests in formations of high hydraulic conductivity.” Ground Water 41(5):620-630.

McElwee CD. 2001. “Application of a nonlinear slug test model.” Ground Water 39(5):737-744.

McElwee CD, and MA Zenner. 1998. “A nonlinear model for analysis of slug-test data.” Water Resources Research 34(1):55-66.

Spane, F.A..and D.R. Newcomer. 2004. Results of detailed hydrologic characterization tests - FY 2003. PNNL-14186. Pacific Northwest National Laboratory, Richland, Washington

Spane FA, Jr., PD Thorne, and DR Newcomer. 2001a. Results of detailed hydrologic characterization tests - FY 1999. PNNL-13378, Pacific Northwest National Laboratory, Richland, Washington.

Spane FA, Jr., PD Thorne, and DR Newcomer. 2001b. Results of detailed hydrologic characterization tests - FY 2000. PNNL-13514, Pacific Northwest National Laboratory, Richland, Washington.

Spane FA, Jr., PD Thorne, and DR Newcomer. 2002. Results of detailed hydrologic characterization tests - FY 2001. PNNL-14113, Pacific Northwest National Laboratory, Richland, Washington.

Spane FA, Jr., PD Thorne, and DR Newcomer. 2003. Results of detailed hydrologic characterization tests - FY 2002. PNNL-14186, Pacific Northwest National Laboratory, Richland, Washington.

Springer RK, and LW Gelhar. 1991. "Characterization of large-scale aquifer heterogeneity in glacial outwash by analysis of slug tests with oscillatory response, Cape Cod, Massachusetts.” In: U.S. Geological Survey Water Resources Investigations. Report 91-4034:36-40.

Thorne PD, MA Chamness, FA Spane, Jr., VR Vermeul, and WD Webber. 1993. Three-dimensional conceptual model for the Hanford Site unconfined aquifer system, FY 93 status report. PNL-8971, Pacific Northwest Laboratory, Richland, Washington. 
Williams BA, MJ Nimmons, RE Peterson, BN Bjornstad, DC Lanigan, RJ Serne, FA Spane, and ML Rockhold. 2007. Limited Field Investigation Report for Uranium Contamination in the 300 Area, 300FF-5 Operable Unit, Hanford Site, Washington. PNNL-16435. Pacific Northwest National Laboratory, Richland, Washington.

Zubruchen BR, VA Zlotnik, and JJ Butler, Jr. 2002. "Dynamic interpretation of slug tests in highly permeable aquifers.” Water Resources Research, 38(3):10.1029/2001WR000354. 
Appendix A. Well 399-3-21 Borehole Log 



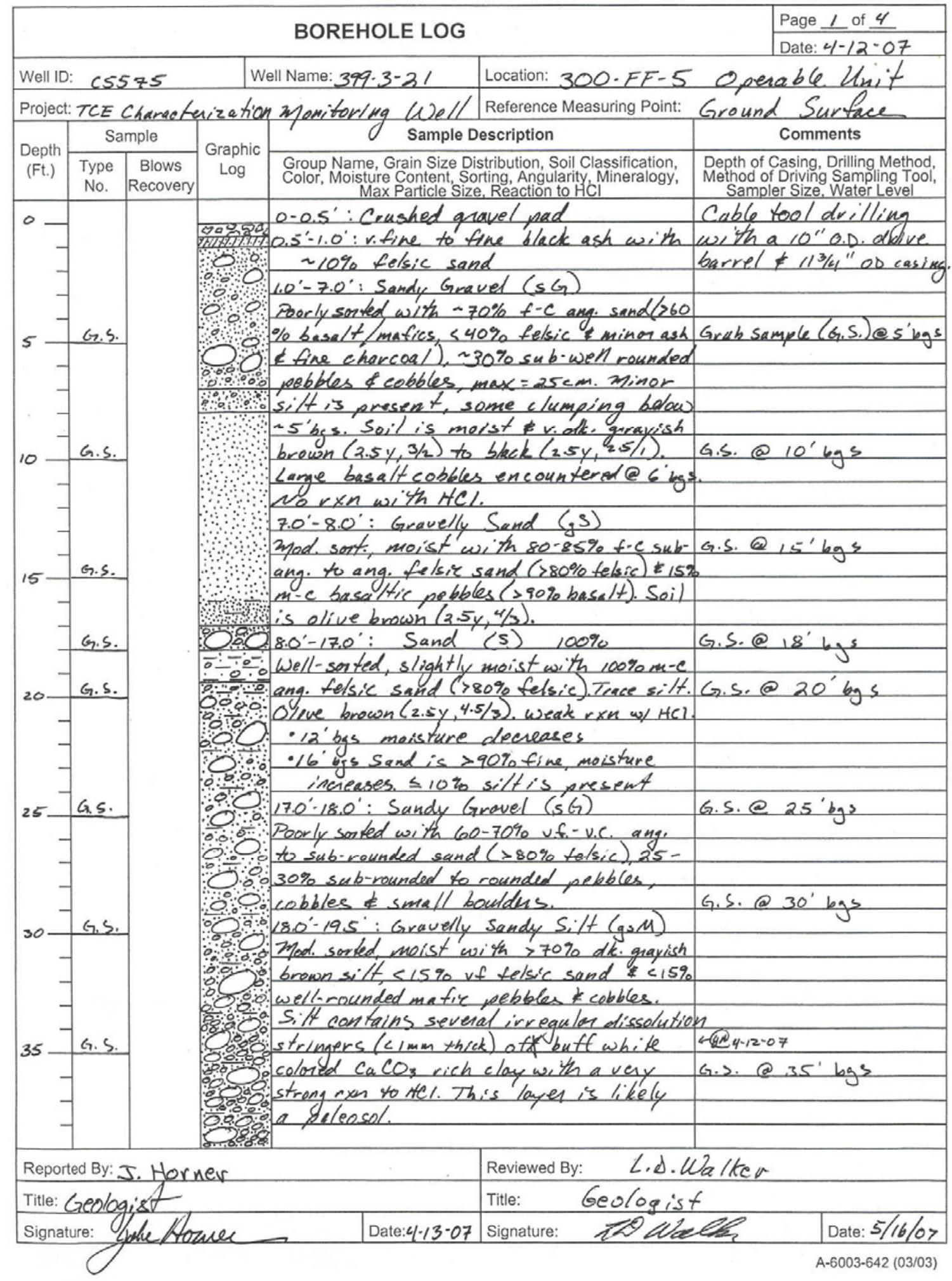

Figure A.1. Borehole Log for Well 399-3-21 


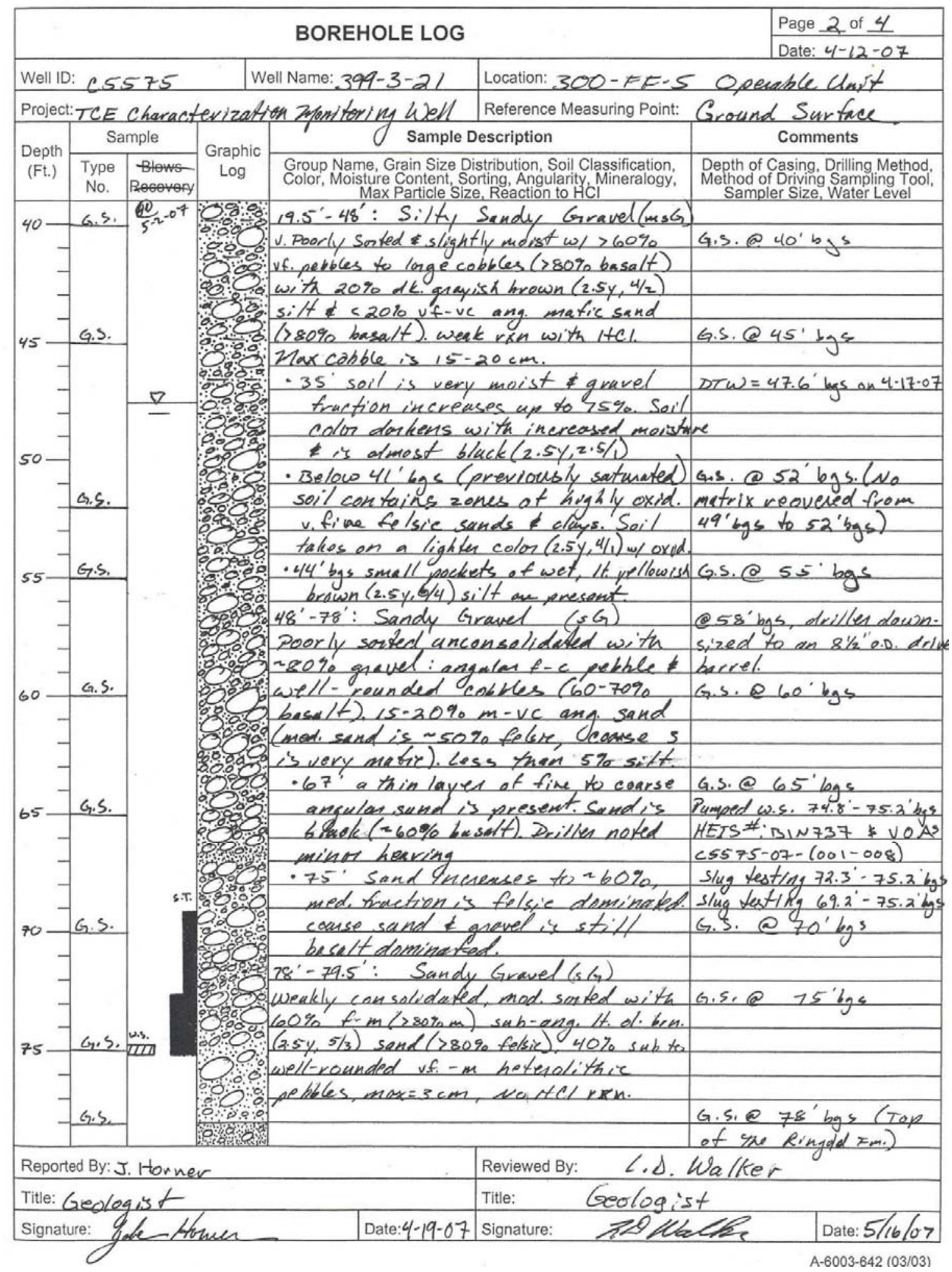

Figure A.1 (Cont.) 


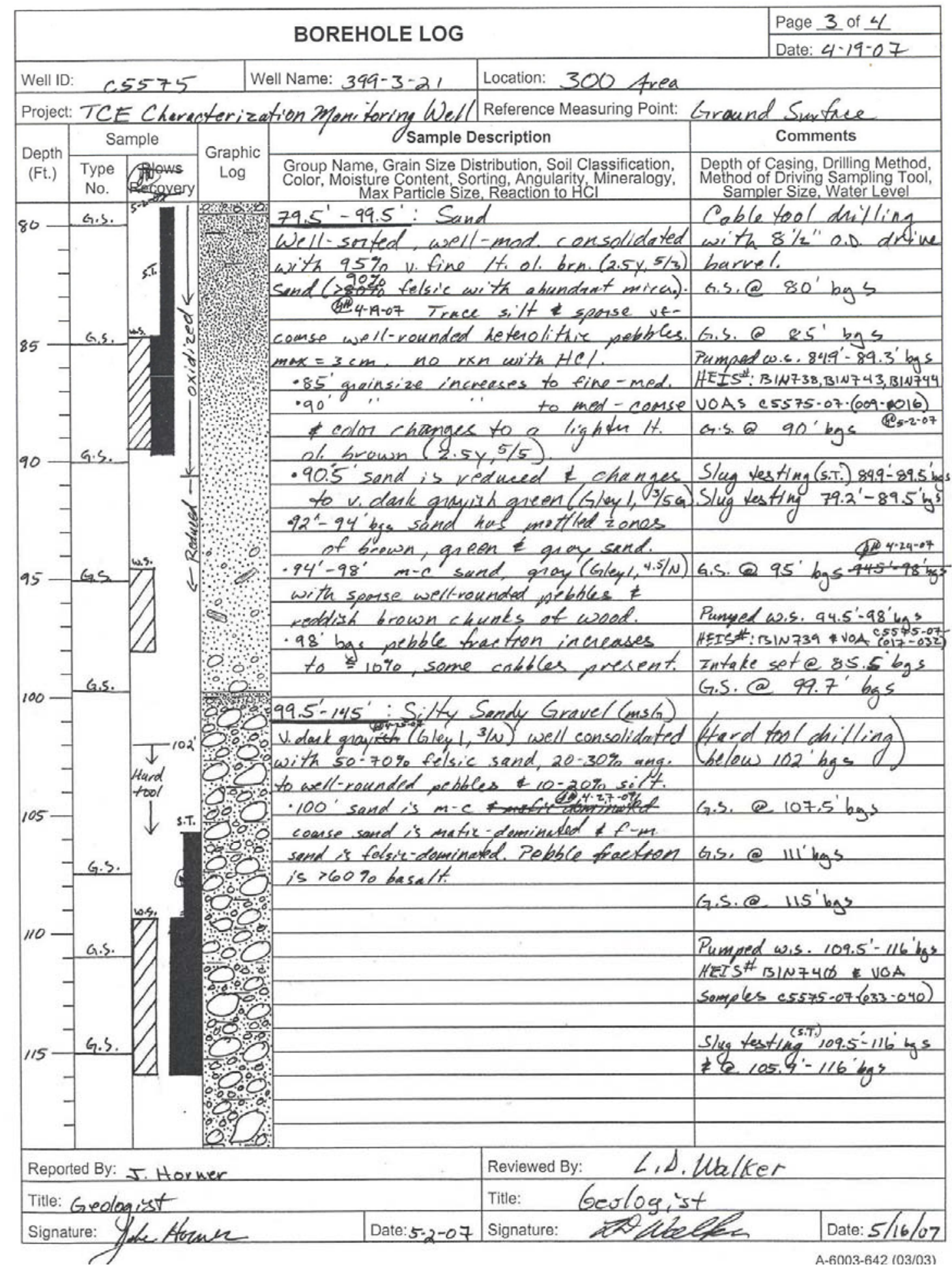

Figure A.1 (Cont.) 


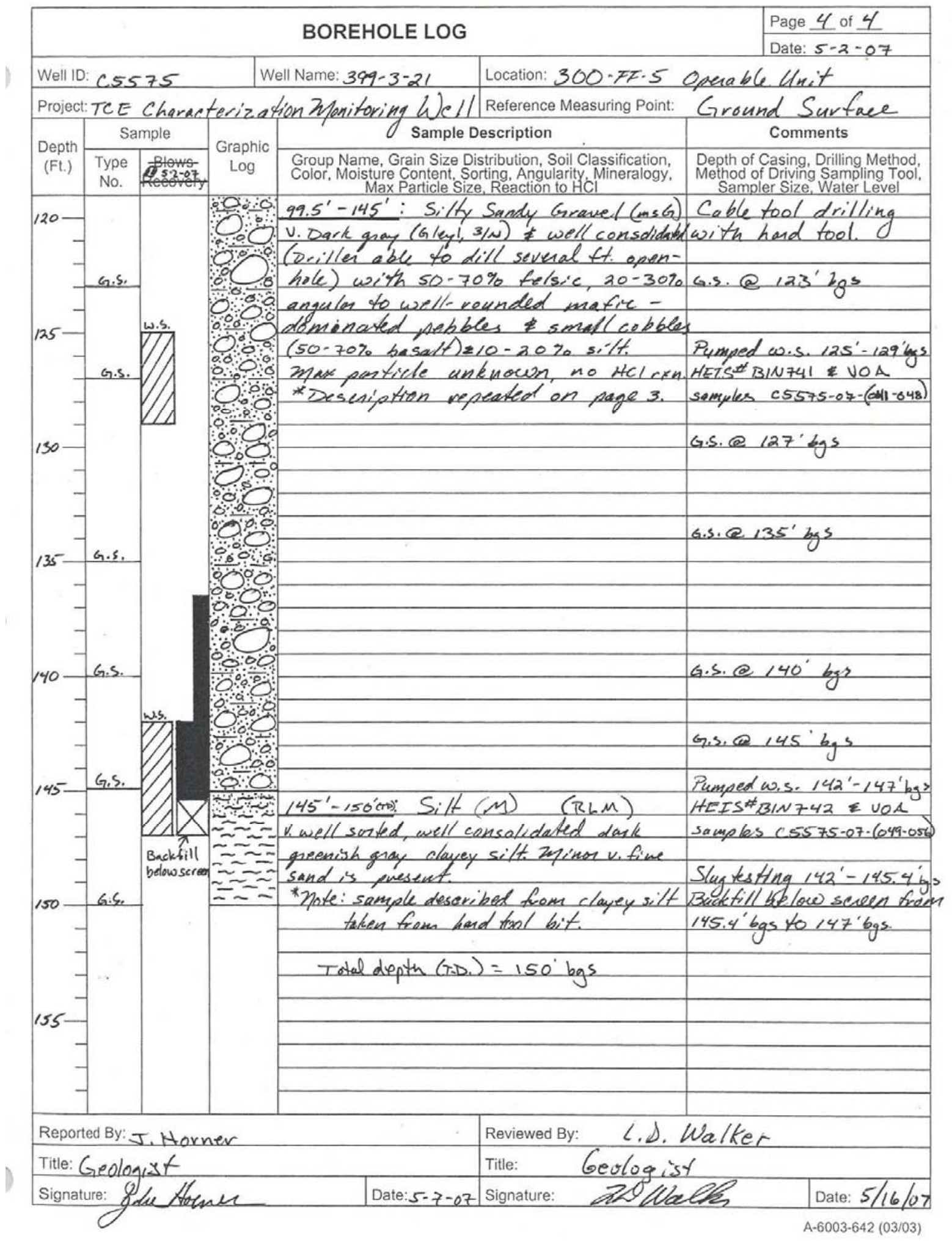

Figure A.1 (Cont.) 


\section{Appendix B. Miscellaneous Test Equipment Pictures}

(Note: no pictures of the actual packer/well-screen test system used in testing well 399-3-21 during borehole advancement are available. The following pictures are of a very similar packer/well-screen test system [i.e., length and dimensions] that was used during advancement and testing of selected CERCLA Operable Unit UP-1 wells, as reported in Spane and Newcomer. ${ }^{(a)}$ )

(a) FA Spane, and DR Newcomer. 2005. Slug Test Characterization Results for Multi- Test/Depth Intervals Conducted During the Drilling of CERCLA Operable Unit OU UP-1 Wells 299-W19-48, 699-30-66, and 69936-70B. Letter report to Mark Byrnes (Fluor-Hanford ORP), September 13, 2005, 49p. 



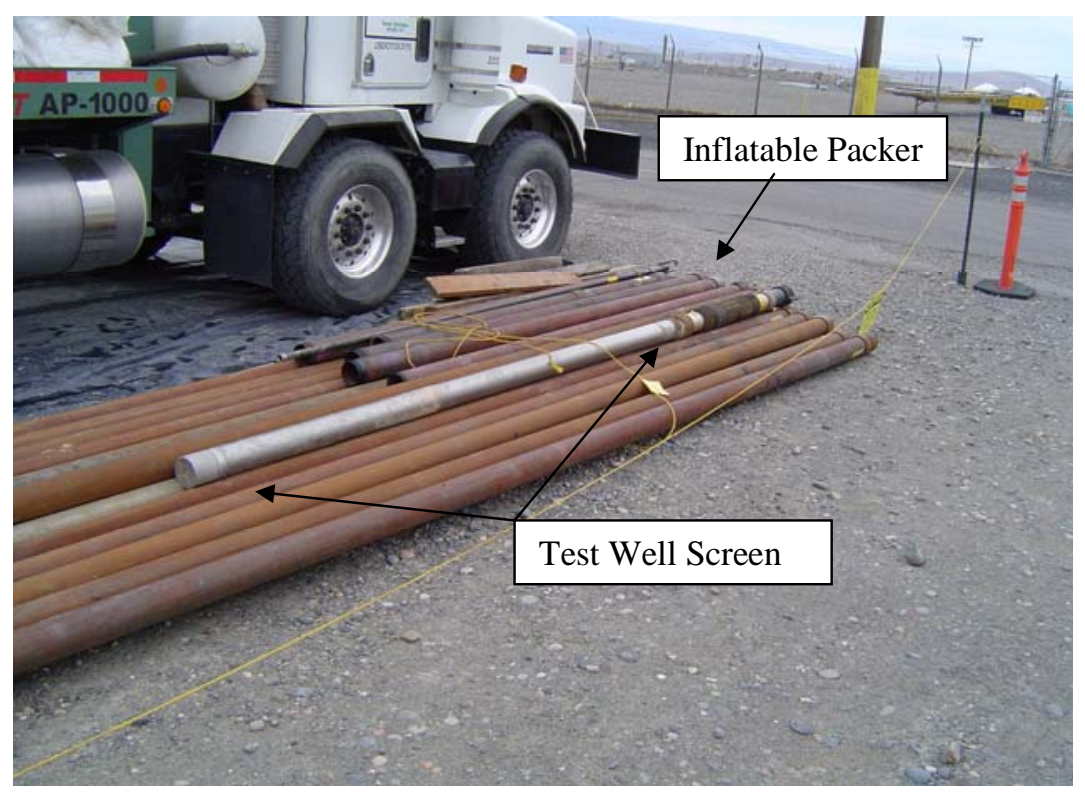

Figure B.1. Inflatable Packer and Well-Screen Assembly Shown on Pipe Rack

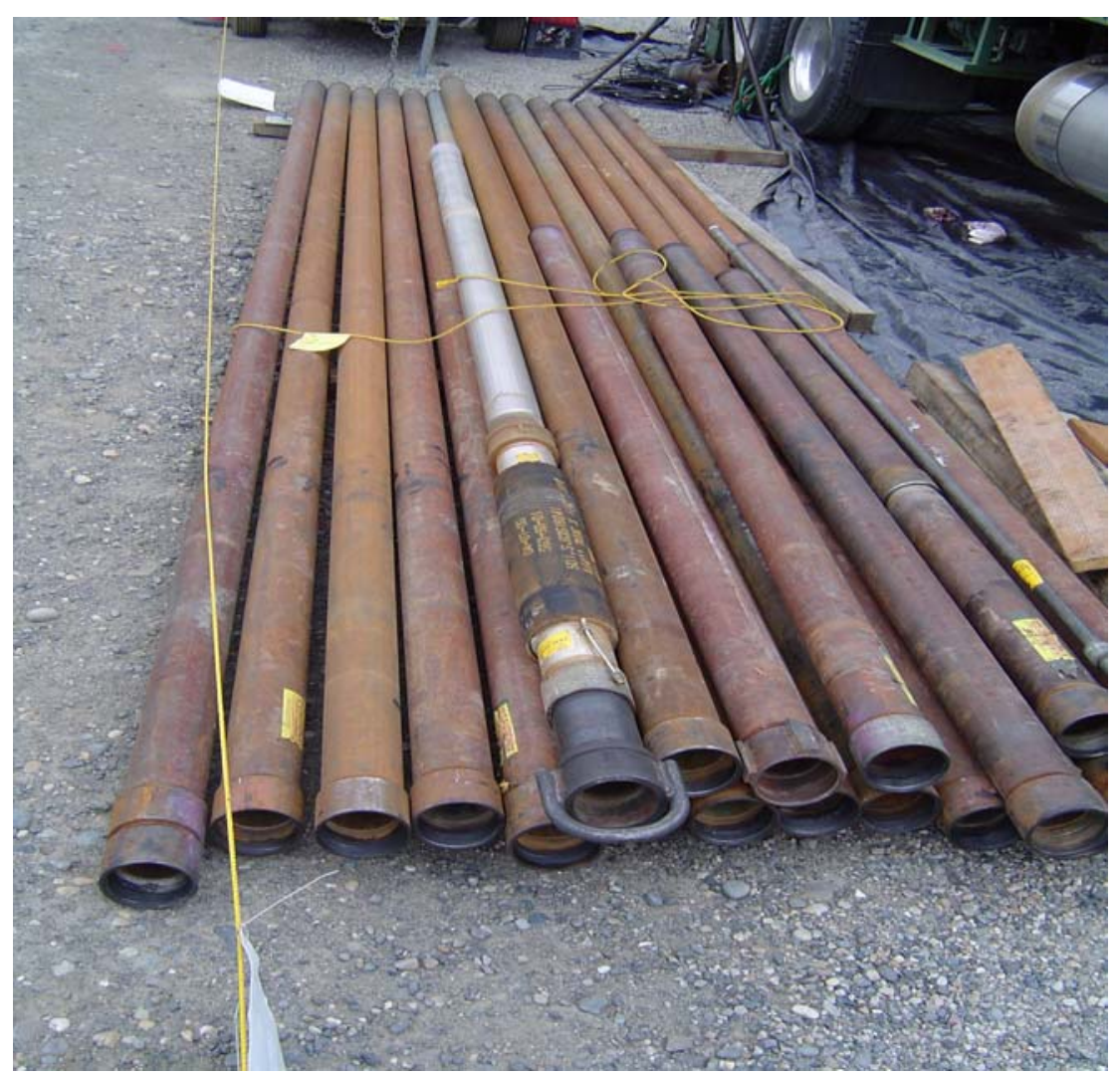

Figure B.2. Closer View of Packer/Well-Screen 


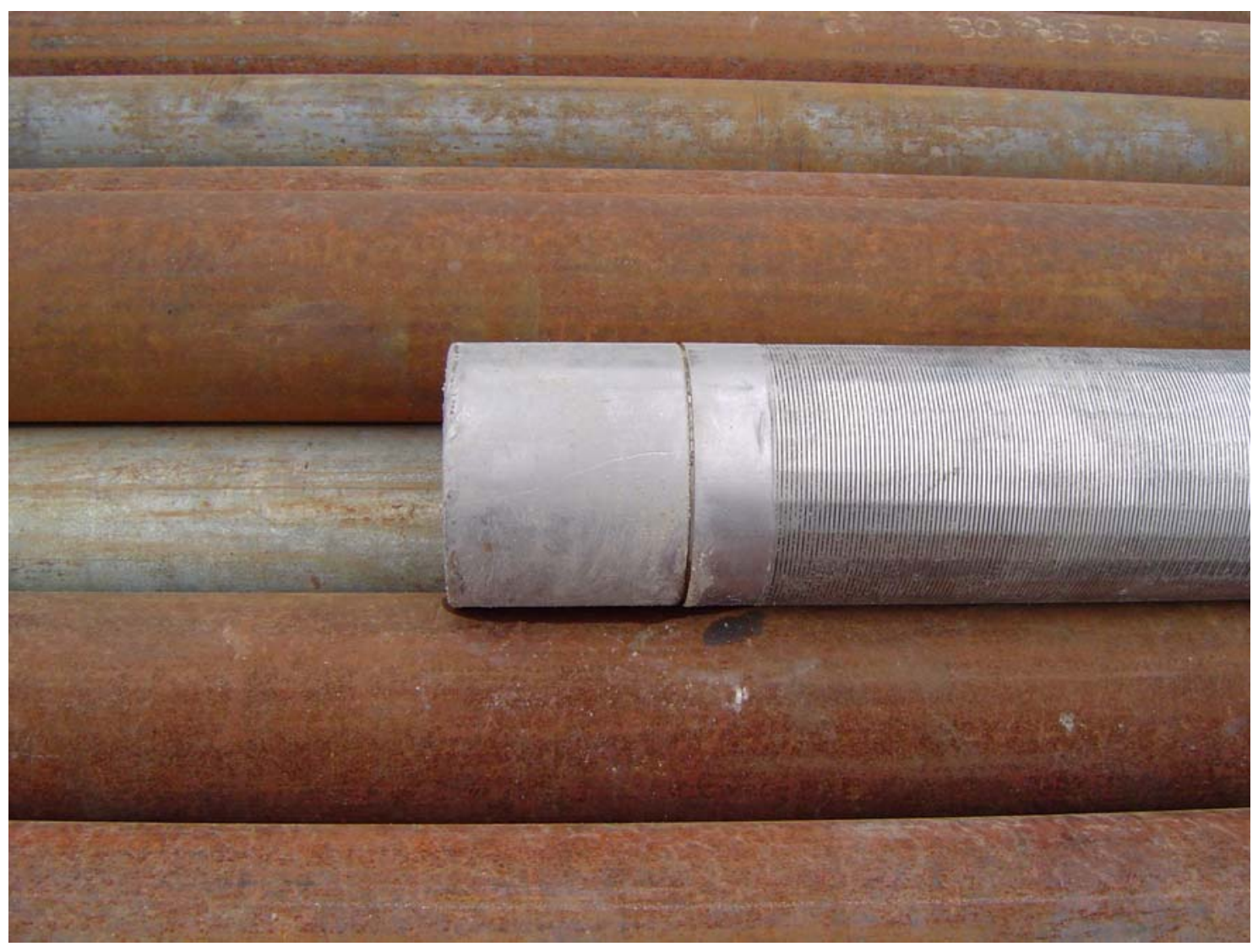

Figure B.3. Close-up View of Test Well Screen and Bottom End-Cap 
PNNL-16732

\section{Distribution}

No. of

Copies

\section{ONSITE}

4 Fluor Hanford

J. V. Borghese

S. P. Luttrell

L. C. Swanson

B. A. Williams

1 CH2M Hill

M. Connelly

8 Pacific Northwest National Laboratory

J. S. Fruchter

K6-96

D. C. Lanigan

K6-75

M. L. Rockhold

K9-36

R. M. Smith

K6-96

F. A. Spane

K6-96

P. D. Thorne

K6-96

M. D. Williams

K6-96

S. B. Yabusaki

K9-36

Distr. 1 